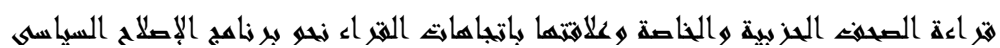

\title{
تمهـد:
}

تمنتل الصحف الحزبية و الخاصة إحدى قنوات الاتصال الهامة فى المجتمع المصرى، إذ تعمل بجانب الصحف القومية ووسائل الإعلام الأخرى على تزويد القارئ بالمعلومات عن القضايا و المشكلات المختلفة.

وقد استطاعت هذه الصحف - الحزبية و الخاصة - وبفضل ما تمتعت بـــه

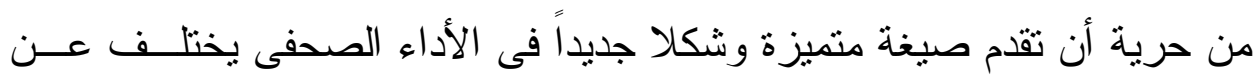

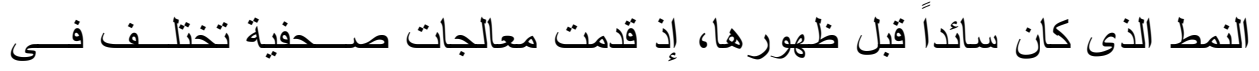
توجهاتها السياسية و الفكرية عن الصحف القومية التى ترنبط بدرجة أو بـأخرى بالتوجهات و السياسات الحكومية.

بالإضافة إلى هذا فقد تحقق للعديد من الصحف الحزبية و الخاصة الاستقر ار

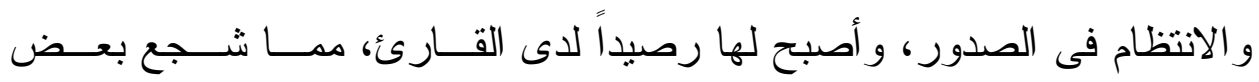
الصحف الحزبية إلى أن تتحول من الإصدار الأسبوعى إلى الإصدار اليومى منل وهل الوفد و الأحر ار ، وكذلك صدرت بعض الصحف اليومية الخاصة مثتـل نهضــــة الإسة مصر و المصرى اليوم. - مصن.

وفى ظل نظام سياسى يقوم على التعددية السياسية، وكذلك فى ظل السعى نحو إيجاد سوق مفتوحة للآر اء، تأتى الصحف الحزبية و الخاصة كترجمة فعلية

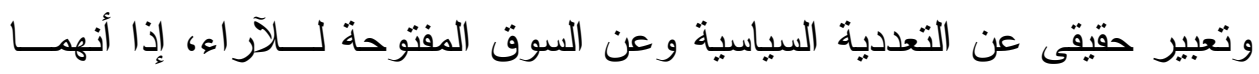
الوسيلتان الأكثر تعبيراً عن التطور ات السياسية و الصحفية التى شهدها المجتمــع ونع المصرى فى السنوات الأخيرة والتى تبلورت فى الدعوة إلى الإصـاحح السياسـى الثشامل. وفى مجال قياس فعالية أدوات الحزب السياسى تبرز الصحيفة الحزبيــة

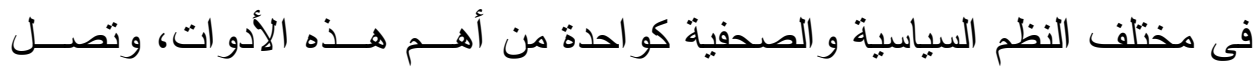
أهميتها فى بعض النظم إلى حد أنها - أى الصحيفة - هى الحزب وتكون أكثــر فعالية من الحزب نفسه('). 


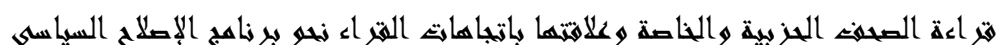

وتعبر التجربة الحزبية المصرية فى الماضى و الحاضر عن هذه الحقيةــة بصورة و اضحة، إذ تعرف الأحز اب بأسماء الصحف، كما توصــف الأحــز اب السياسية المصرية بأنها أحز اب صحفية. وقد تطورت النظرة إلى صحافة الأحز اب فى الأنظمة السياسية و الإعلامية المختلفة عبر تجارب عديدة، وتحددت وضعيتها بين أدوات الحــزب السياســى الأخرى إنطلاقاً من رؤية النظام للأحز اب السياسية ومدى سماحه لها باســتخدام أدو اتها المتاحة، و على هذا الأساس فإن مكانة الصحافة الحزبية ترتبط بعدد مـنـ العو امل التى تشكل فى مجملها فلسفة النظام السياسـىى، فهـى - أى صــــافة الأحز اب - تكون الأداة الرئيسية لأحز ابها حين يعجز النظام البرلمانى عن تمثيل مختلف القيادات السياسية، وحين يفثل النظام السياسى فى ضمان حرية العمـلـل السياسى، وتكون الصحيفة الحزبية هى الأداة الوحيدة حين يشتد القهع السياسى()(

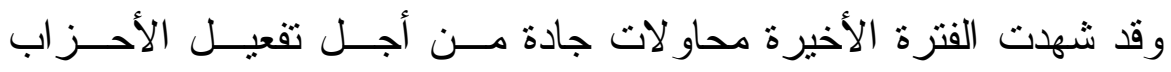
السياسية/المصرية ودفعها للمشاركة بصورة أكثر فعالية فى الحياة السياسية، وقد تمثلت هذه المحاو لات فى المبادرة التى طرحها الحزب الوطنى، و الــذى فــتح

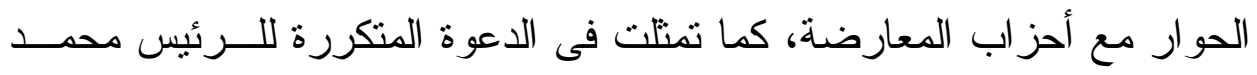
حسنى مبارك لأحز اب المعارضة بأن تقوم بدورها كجزء من النظام السياسـى

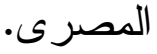

هذا من ناحية ومن ناحية أخرى تعتبر قضية الإصلاح السياسى فى مصر إحدى القضايا المطروحة وبإلحاح فى وسائل الإعلام المصــرية ومسـن بينهــا

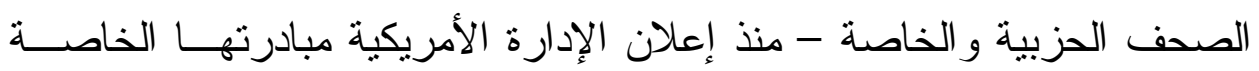
بالثرق الأوسط الكبير، و التى دعت إلى ضرورة الإصـلاح السياسى فى الـدول

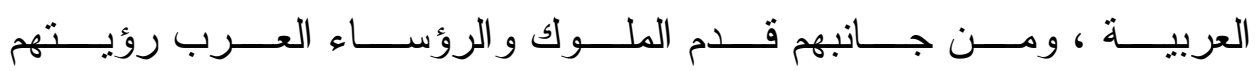




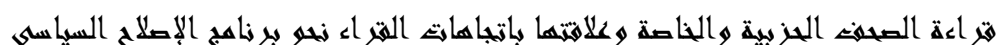

للإصلاح السياسى و التى تضمنتها وثثقة الإسكندرية التى صدرت عن اجتماعهم

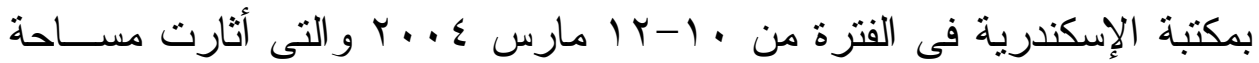
هائلة من الجدل السياسى حول قضية الإصلاح السياسى، وكذلك كانــت قضـــية

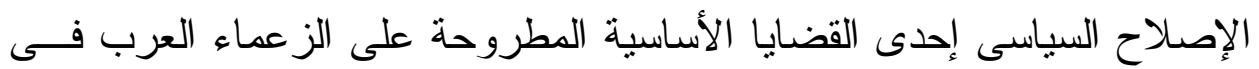

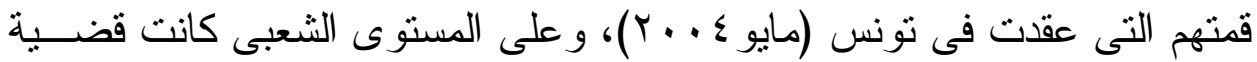
الإصلاح السياسى موضوعاً للعديد من المؤتمر ات و الندو ات و والحلقات النقاثشية. ومنذ أن طرحت قضية الإصلاح السياسى على الساحة، والصحف الحزبية

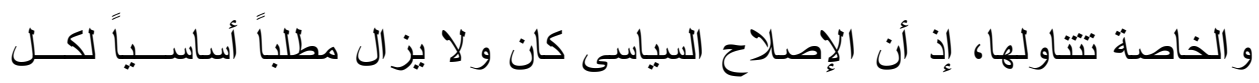
القوى و الأحز اب السياسية على اختلاف توجهاتها الفكرية و السياسية. وتسعى هذه الدر اسة إلى رصد العلاقة بـين قــر اءة الصـــف الحزبيـــة و الخاصة و اتجاهات القراء نحو الإصلاح السياسى.

\section{الإطار النظرى:}

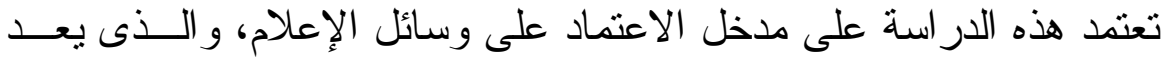

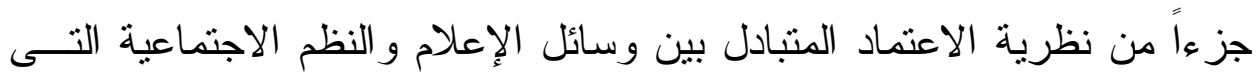

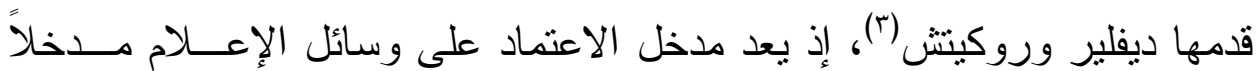

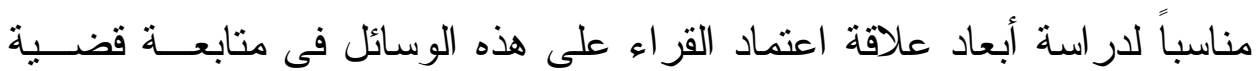

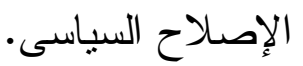

وكما توحى النظرية فإن العلاقة الرئيسية النى يقوم عليها منطق هذا النهج

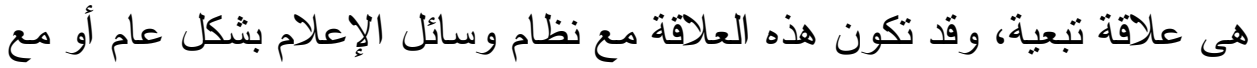

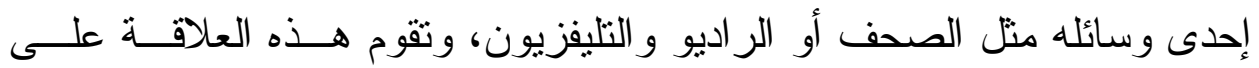

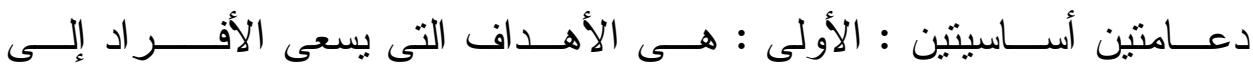




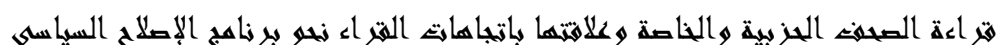

تحقيقها من خلال المعلومات التى توفر ها المصادر المختلفة، و الثانيــة: هــــ أن

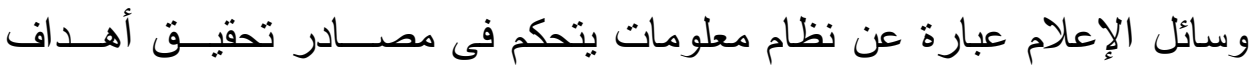
الأفر اد، وتتمثل هذه المصادر فى مر احل جمع المعلومات وتتسيقها ونشر هاء (؛).

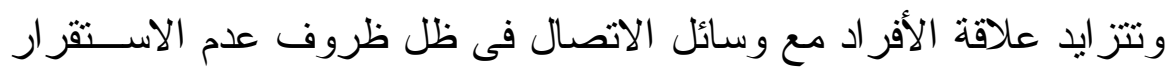

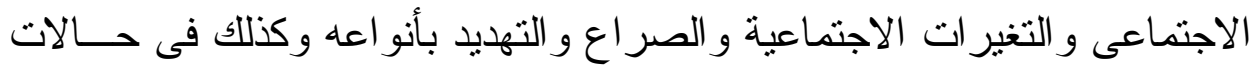

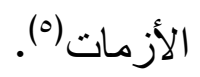

\section{ويفترض مدخل الاعتماد على وسائل الإعلام ما يلحى (؟):}

- تختلف الأنظمة الاجتماعية وفقاً لدرجة استقر ارها، وكلما زادت درجــة عدم الاستقرار، زادت الحاجة إلى البحث عن المعلومات.

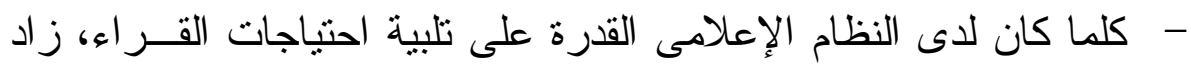

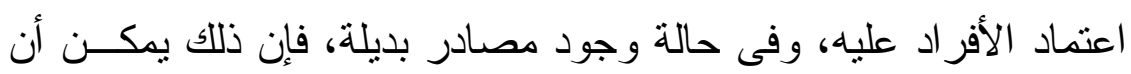
يقلل من اعتماد الأفر اد على وسائل الإعلام.

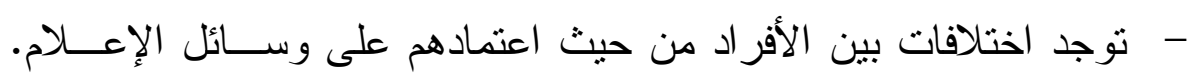

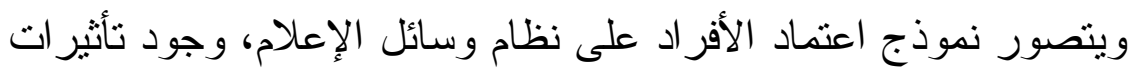

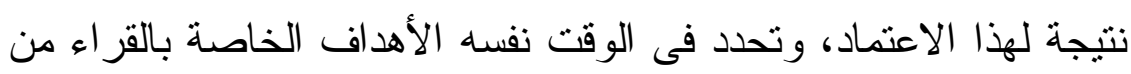

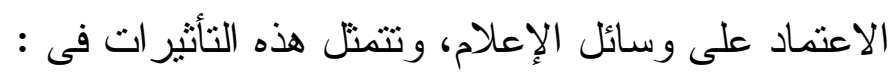

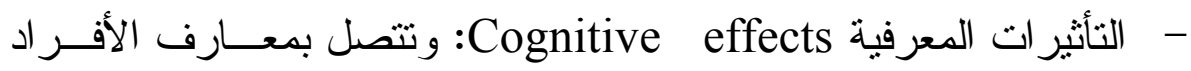
ومعلوماتهم وتكوين الاتجاهات وترتيب الأولويات.

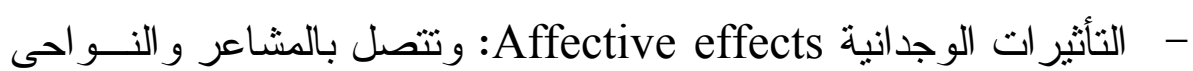
العاطفية منل القلق و الخوف و التأثير ات الأخلاقية و المعنوية. 


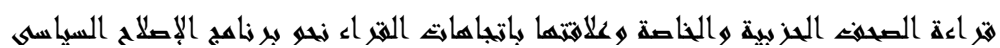

- التأثير ات السلوكية Behavioral effects : وهى خاصة بـالتغير فـى

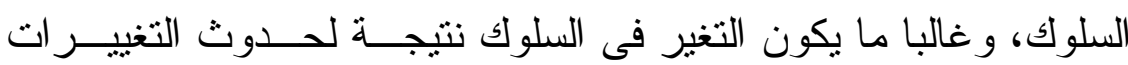

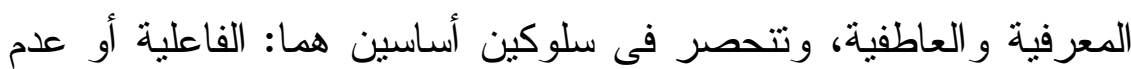

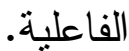

وقد طور ديفلير وروكينت نموذج الاعتماد على وسائل الإعلام كالتالى (v)

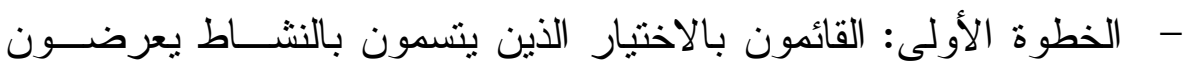

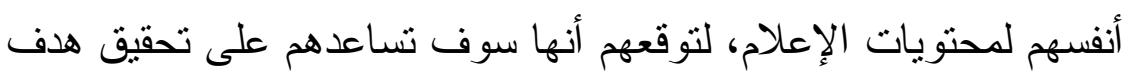
أو أكثر من الفهم أو التوجيه أو النسلية.

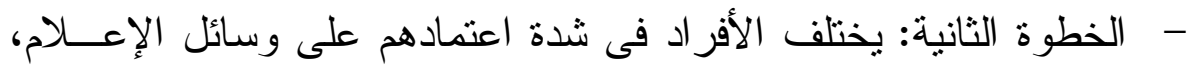

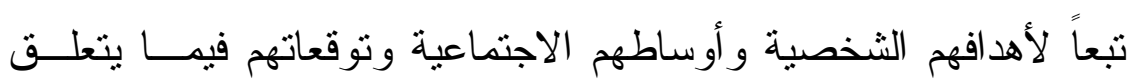

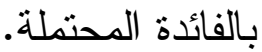
- - الخطوة الثالثة: وفيها تزداد درجة المشاركة النشطة فى تتسيق و استيعاب المعلومات وفقا لدرجة الاستتارة المعرفية و العاطفية.

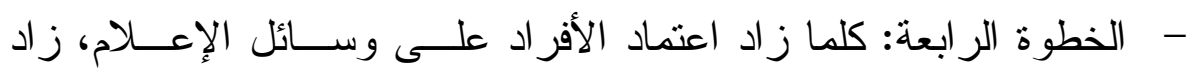
احتمال حدوث الثأثثر ات الإدر اكية و السلوكية الطويلة الأمد.

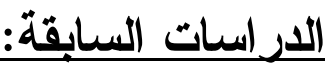

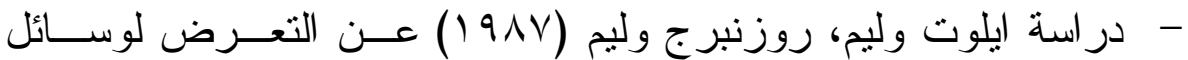

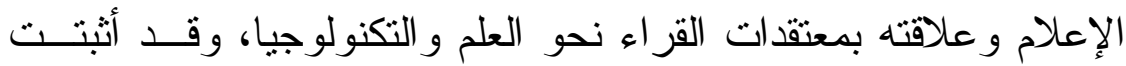
الدراسة أن التعرض للمعلومات العلمية التى تقدمها وسائل الإعلام يؤدى

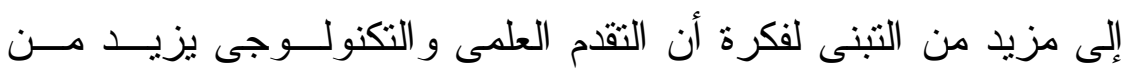

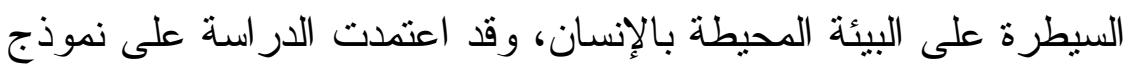
الاعتماد على وسائل الإعلام (^). 


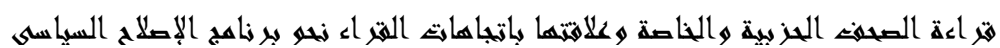

- - در اسة جر انت Grant و آخرون (1991 ) التى اهتمت بتحليـل ظـــاهرة

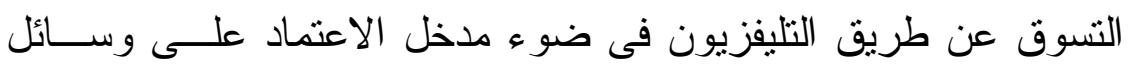

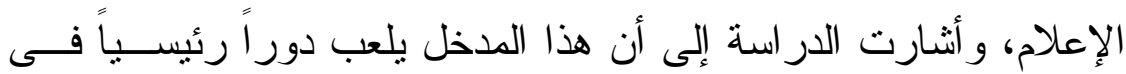

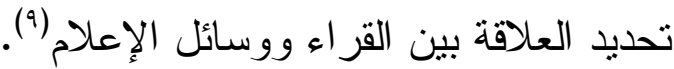
- - دراسة عزة عبد العظيم (ب999) عن الاعتماد على التليفزيون ومــى الاعلى

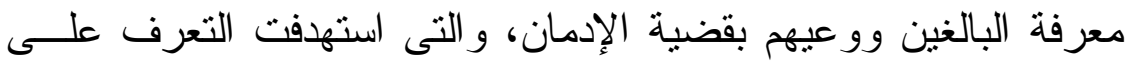
مدى اعتماد البالغين على التلافزيون كمصدر للمعلومات عـن مشــكلة التهات الإدمان، وقد كثفت الدراسة عن عدم وجود علاقة ارتباطية بين الاعتماد على التليفزيون فى الحصول على المعلومسـات عـن قضـــية الإدمــان ومستوى المعرفة حول هذه القضية(· ('). - - در اسة ماك دونالد Mc Donald (1999) و التىى استهدفت تحليل أنماط استخدام القر اء لوسائل الإعلام، وتحديد أسس اعتماد القز اء على وســبلة الإعلام المناسبة للحصول على المعلومات السياسية(')

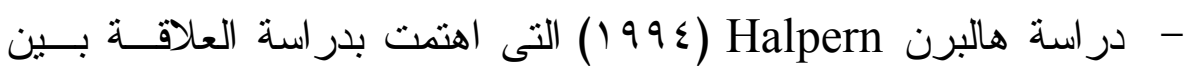

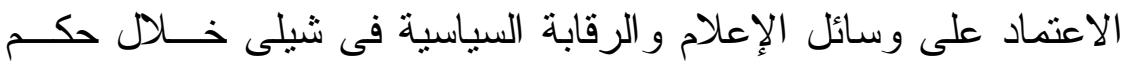

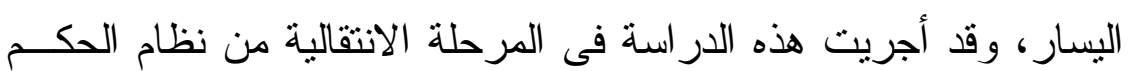

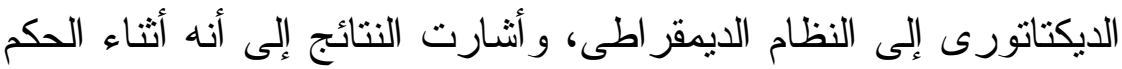

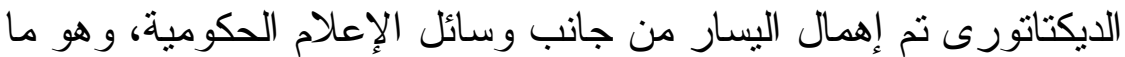

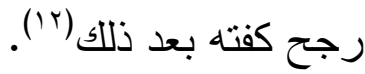

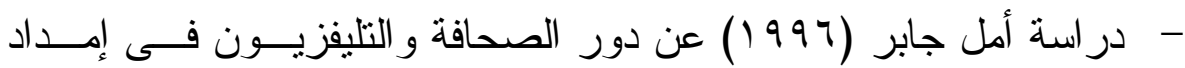

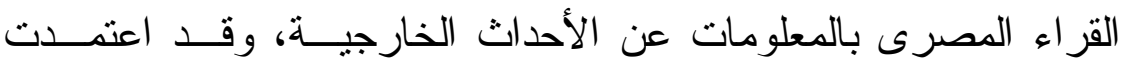

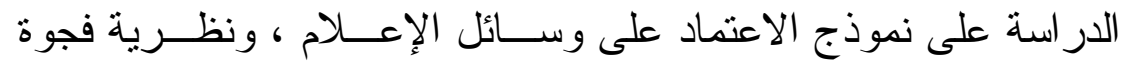




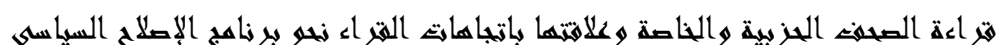

المعرفة فى اختبار مستوى معرفة القر اء بحدثين نالا اهتمامــاً كبيــراً فــى الصحف و التليفزيون هما: "الاعتداء الإسر ائيلى على لبنان، ومرض جنــــن

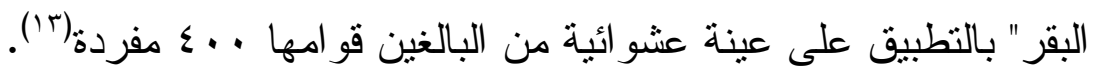

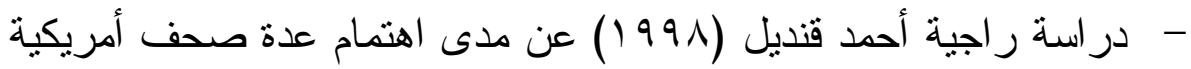

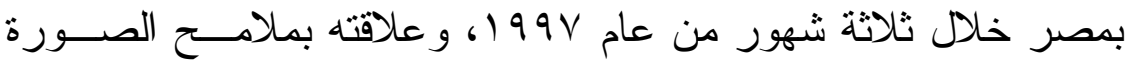

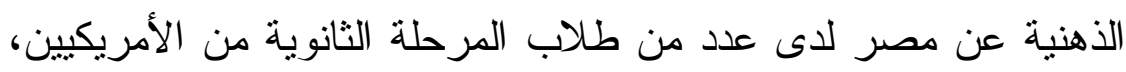
حيث خلصت الدر اسة إلى تضاؤل الاهتمام بمصر على مستوى الصحف

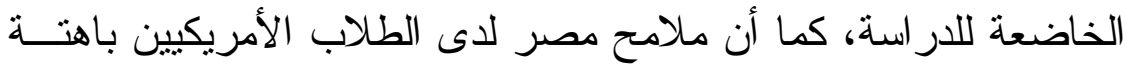
سطحية، وهناك خلط بين الإسلام و الإرهاب و التطرف فى تصور الطلبة

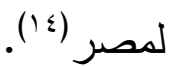

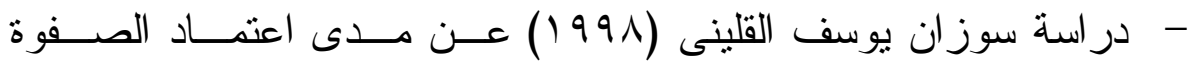
المصرية على التليفزيون المصرى فى أوقات الأزمات، و التى استهدفت التعرف على مدى قدرة التليفزيون الدصرى على جذب أفراد الصــفوة

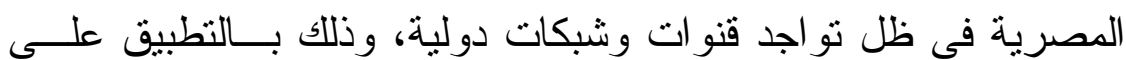

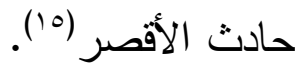
- - در اسة ليلى حسن السيد (1991) عن دور وسائل الاتصال فــى إمــداد طلاب الجامعات المصرية بالمعلومات عن الأحداث الجارية فى إطــار

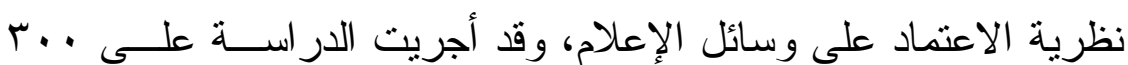
مفردة موزعة على ثلاث جامعات مصرية ( حلوان - الأزهر - السادس الاس

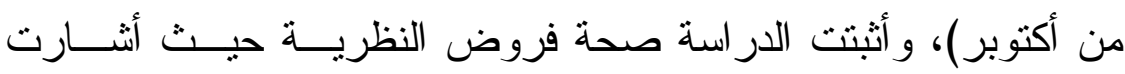

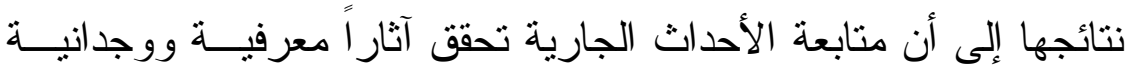

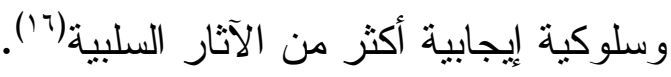




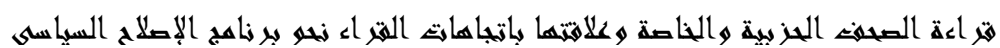

- دراسة محمود خليل (991) عن دور الصحف الحزبية فـى تتــكيل

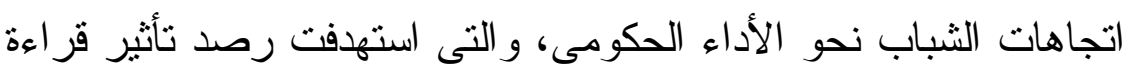

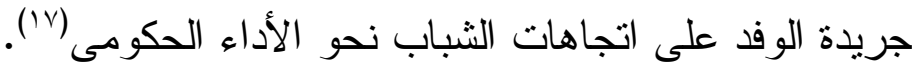

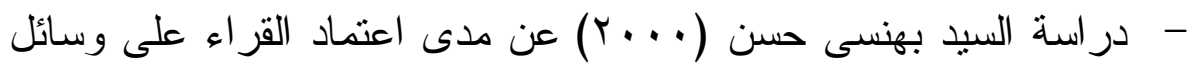

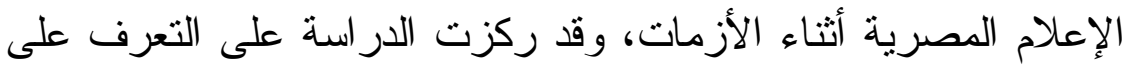
أبعاد علاقات اعتماد طلاب الجامعات على وسائل الإعلام المصرية أثناء

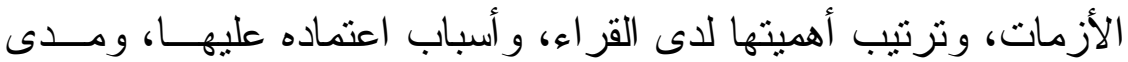
شدة تقته بها، و العلاقة بين هذه النقة وشدة الاعتماد (^)'.

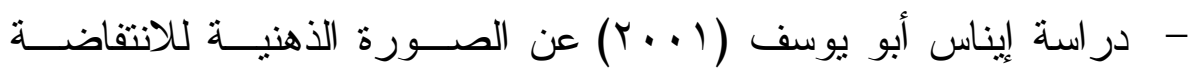
الفلسطينية لاى النشء و التى اعتمدت على نموذج الاعتماد على وســائل الإعلام للتعرف على الوسائل الاتصالية المفضلة لدى النشء فى متابعــة أحداث الانتفاضة الفلسطينية(19).

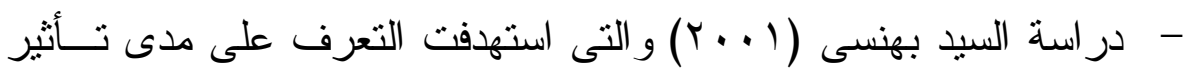

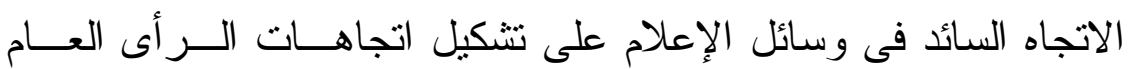

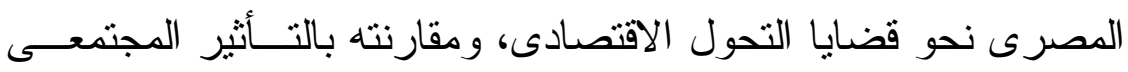

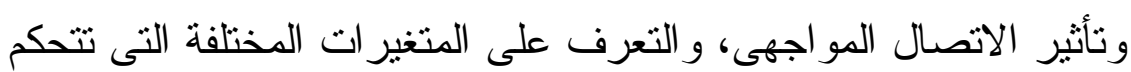
فى استعداد الأفر اد للتعبير عن آر ائهم بشكل معلن (·r)".

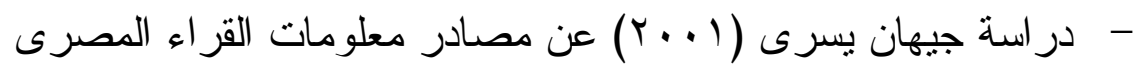

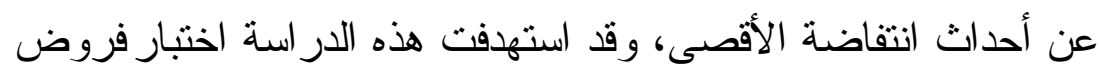

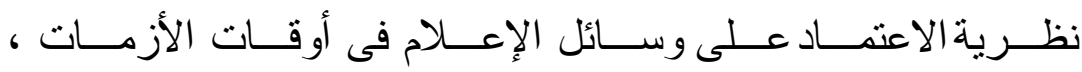




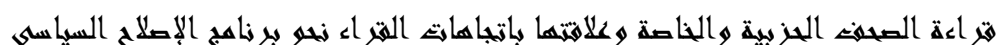

بالتطبيق على انتفاضة الأقصى ، وتقييم الدور الذى قامت به وسائل الإعلام

المصرية و العربية فى تغطية أحداث الانتفاضة. (rا').

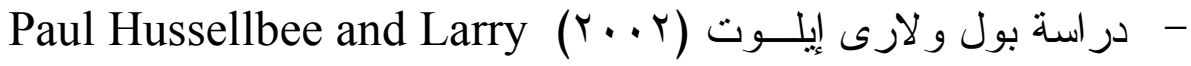
Elliott و إدر الك الر أى العام للمشكلات العامة، من خلال تحليل تغطية الصــــف القومية و المحلية لالثين من الجر ائم(rr).

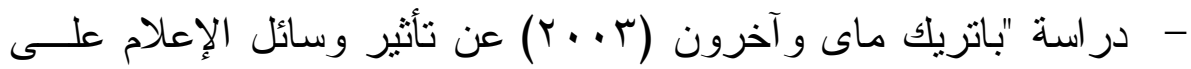
الر أى العام و التى استهدفت التعرف على مدى المساندة العامة لإضر اب المحررين الصحفيين فى اثثين من صحف العاصمة وقد ركزت الدر اسة على تأثير رؤية القر اء للصحفيين و أخبار وسائل الإعلام علــى تشـــيل

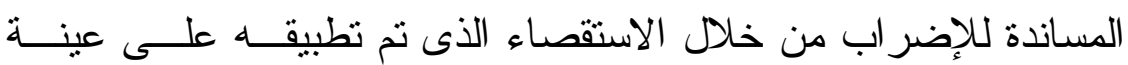
قو امها 07 كـ من المبحوثين (rr). مشكثة الدر (سية:

فى ظل مناخ الحرية الذى تمتعت به الصحف الحزبية و الخاصة، استطاعت هذه الصحف أن تتتاول موضو عات وتتاقش قضايا لم تكن لتستطيع تتاولها مـن قبل و هذه الدر اسة لا تؤر خ للإصصلاح السياسى فى مصر ، و إنمـــا تســى إلـى

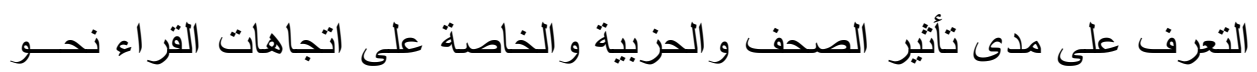
الإصلاح السياسى ومدى اعتمادهم على هذه الصحف فى متابعة قضية الإصلاح السياسى، إذ أن هذه الصحف تعبر عن رؤى منباينة و اتجاهات سياسية متتوعة، ومعالجات صحفية تختلف فى كثير من جو انبها - كما سبقت الإثــارة - عـن الصحف القومية. و على ذللك يمكننى أن أعرض مشكلة الدر اسة على النحو التالى: 


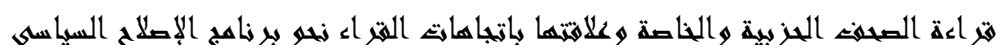

قر اءة الصحف الحزبية و الخاصة و علاقتها باتجاهات القر اء نحو الرؤيـــة

$$
\text { الحكومية للإصلاح السياسى... در اسة ميدانية. }
$$

أهداف الار اسة و أهميتها:

تستهدف هذه الدر اسة التعرف على العلاقة بين قر اءة الصـــحف الحزبيــة و الخاصة وبين اتجاهات القر اء نحو الرؤية الحكومية للإصـلاح السياسى كهـدف رئيسى تتبثق منه عدة أهداف فر عية تتمنل فى وصف:

ا- العلاقة بين كثافة التعرض للصحف و اتجاهات القراء نحـــ الإصــلاح

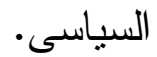

r- العلاقة بين مدى الانتظام فى القر اءة وبين اتجاهات القر اء نحو الإصلاح

$$
\text { السياسى. }
$$

r- العلاقة بين مصداقية الصحيفة لدى القراء و اتجاهاتهم نحـــ الإصــلاح

$$
\text { السياسى. }
$$

ع - العلاقة بين نوع الصحيفة (حزبية - خاصة) وبين اتجاهات القر اء نحو

$$
\text { الإصلاح السياسى. }
$$

\section{وتثمثل أهمية هذه الإراسة فئي}

ا- تنتاول موضو عاً على قدر كبير من الأهمية وهو موضــوع الإصــلاح

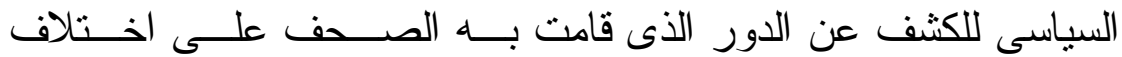

$$
\text { توجهاتها فى هذا الإطار • }
$$

r- تتناول الدر اسة عدة عناصر تزتبط بعملية قر اعة الصحف، للكثف عـن

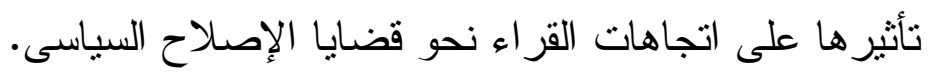

ب- تحدد الدر اسة بأسلوب علمى مدى اعتماد القر اء على الصحف فى متابعة

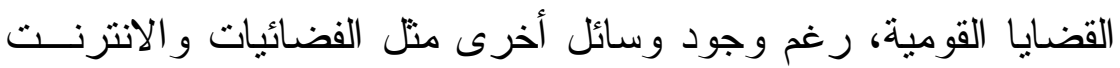

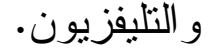




\section{فروض الاراسة:}

تتطلق هذه الدر اسة من فرض رئيسى تمت صباغته على النحو النالى:

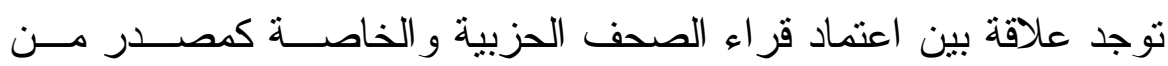
مصادر المعلومات عن قضية الإصلاح السياسى وبين اتجاهاتهم نحو الإصــلاح السياسى.

وينبثق من هذا الفرض الرئيسى، الفروض الفرعية التالية:

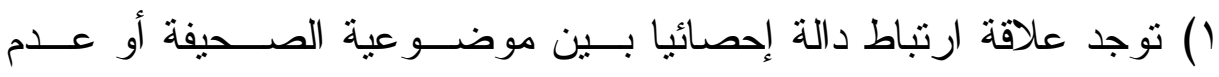

موضو عيتها فى عرض قضية الإصلاح السياسى وبين اتجاهات القراء نحو لئه الإصلاح السياسى.

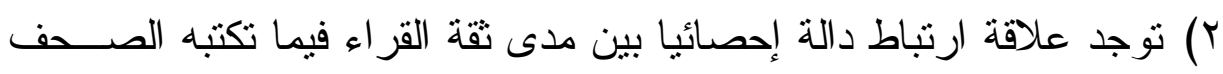

الحزبية والخاصة عن الإصلاح السياسى، وبين اتجاهاتهم نحو الإصــلاح

$$
\text { السياسى. }
$$

r) توجد علاقة ارتباط دالة إحصائياً بين مستوى التعرض - معدل القراءة للصحف الحزبية والخاصة وبين اتجاهات القراء نحو الإصلاح السياسى.

\section{الإطار المنهجى للار اسة:}

$$
\text { ا - نوع الار اسة: }
$$

تتنمى هذه الدراسة إلى الدراسات الوصفية، إذ تستهدف الكثــف عـن

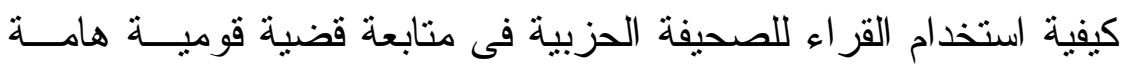
و هى قضية الإصلاح السياسى، ثم الكثف عن العلاقة بين هذا الاستخدام وبين الاتجاهات التى يكونها القراء نحو الإصلاح السياسى. 


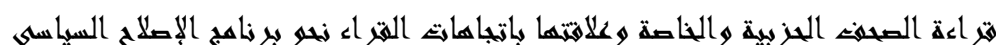

\section{r- منـهج الدراسة:}

تعتمد هذه الدراسة على منهج المســح الإعلامسى - مســح جمهـور الصحف، لوصف وتحليل اتجاهات قر اء الصحف الحزبية و الخاصة نحو

$$
\text { r- الإصلاح السياسى. الدر اسةة: }
$$

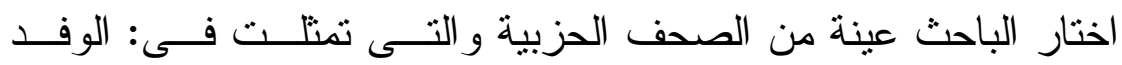

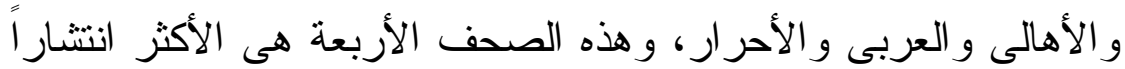

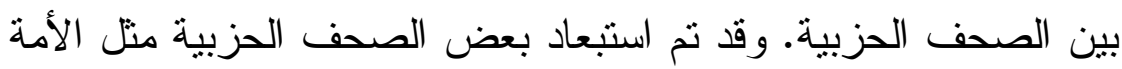

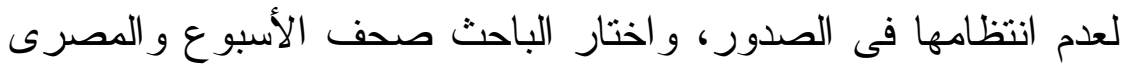
اليوم وصوت الأمة كعينة ممثلة للصحف الخاصة.

\section{ب) عينة القز (اء:}

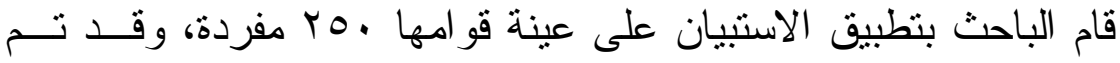
اختبار هذه العينة على مستوى محافظة القاهرة الكبرى، نظر أ لما تتميز به من تتوع فى المستويات الاجتماعية و الاقتصادية و التعليمية. أدوات جمع البيانات:

تعتدد هذه الدراسة على الاستبيان كأداة أساسية لجمع البيانات التى تتعلـق

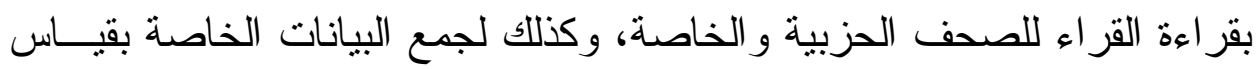

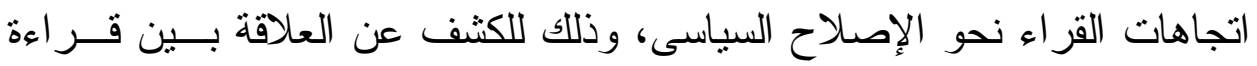

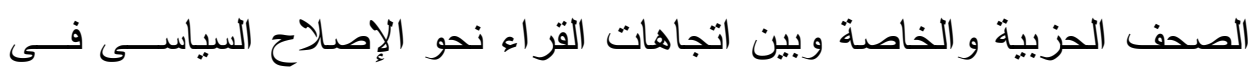




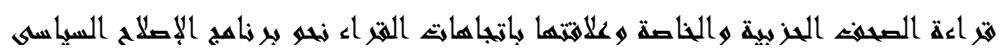

وقد اثتمل مقياس الاتجاه على عشرين عبارة منها عشر عبــار ات تعبـر

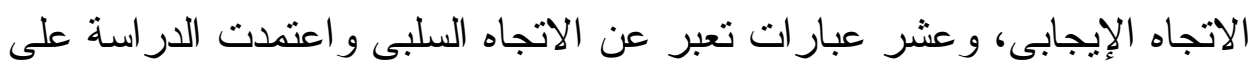

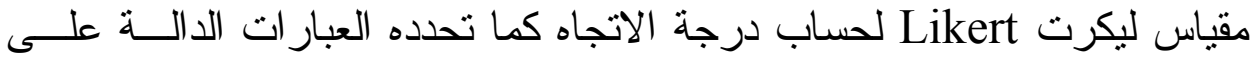
ذلك.

\section{أسلوب التحليل الإحصائى للبيانات:}

اعتمدت الدراسة على الأساليب الإحصائية الثالية: 1- اختبار "ت" T- test ونت استخدامه لدر اسة الفروق بين المتوســطات الحسابية لهجمو عتين من المبحوثين.

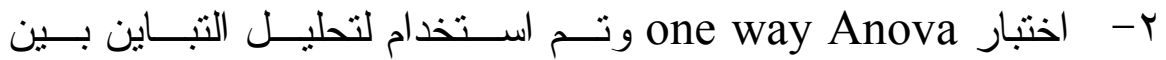
المجموعات فى حالة وجود أكثر من مجمو عتين.

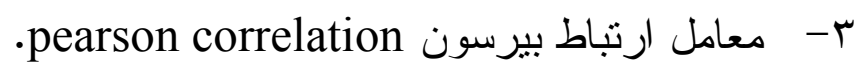
ع - المنوسطات الحسابية و الانحر افات المعيارية. 0- - الجداول التكر ارية. لجر اءعات الصدق والثبات:

تم استخدام أسلوب الصدق الظاهرى لقياس صدق استمارة الاستبيان، وذلك عن طريق عرض استمارة الاستبيان على عدد من المحكمين قبل تطبيقها..

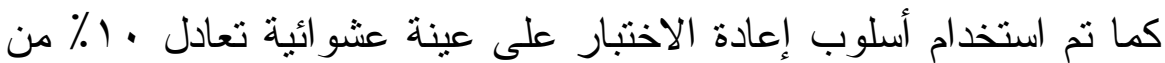

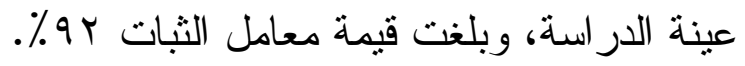
المدى الزمنىى للار اسة: تم تطبيق الدر اسة الميدانية خلال شهرى مايو ويونيو هـ. ـ.

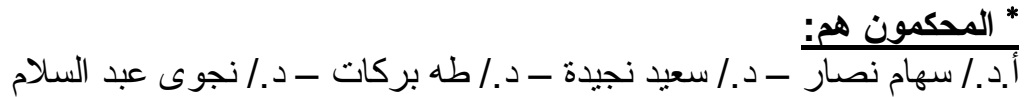




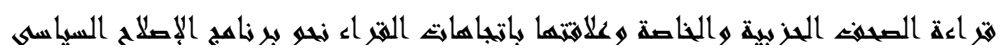

\section{نتائج الدر اسة المبدانبة}

كثفت الدراسة الديدانية التى أجريت على عينة من قراء الصحف الحزبية و الخاصة تكونت من • ro مفردة، عن مجمو عتين من النتائج: المجموعة الأولى: تتعلق بقر اءة الصحف الحزبية و الخاصة لدى المبحوثين.

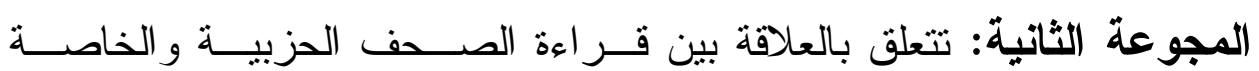

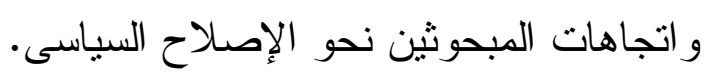
أ) النتائج التى تتعلق بقز اهوة الصحف الحزئية و الخاصة: 1-مدى الاهتمام بالصحف الحزبية والخاصة:

أثنت التحليل الإحصائى الذى أجرى على عينة مـن الصـــف الحزبيــة و الخاصة"، تفاوت اهتمام القراء بالصحف الحزبية و الخاصة، وفى هذا الإطـــار جاءت جريدة الوفد فى مقدمة الصحف الحزبية و الخاصة لاى أفراد العينــة، إذ ولـ

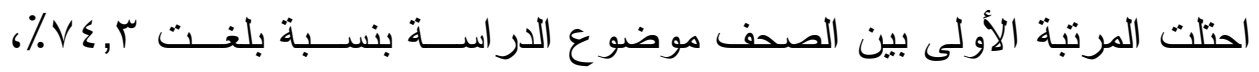
ويمكن تفسير ذللك بأن الجريدة تعبر عن حزب الوفد الجديد والـــى يعـــــــن الأحز اب الهامة، ورغبة القراء فى التعرف على رؤية الحزب للإصلاح السياسى لهنى بالإضافة إلى أنها أول جريدة حزبية يومية، وجاءت جريدة الأسبوع فى الترتيب

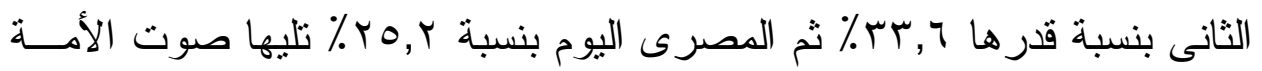

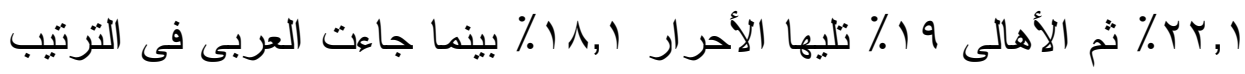

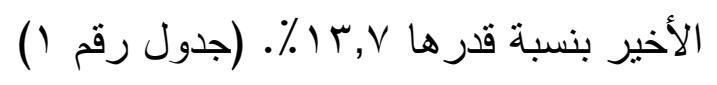

* اثتملت عينة الصحف على:الوفد-الأهلى -الأحر ار - صوت الأمة - العربى - الأسبوع - المصرى اليوم 


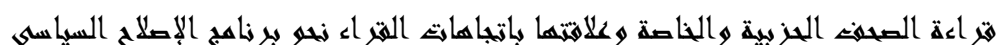

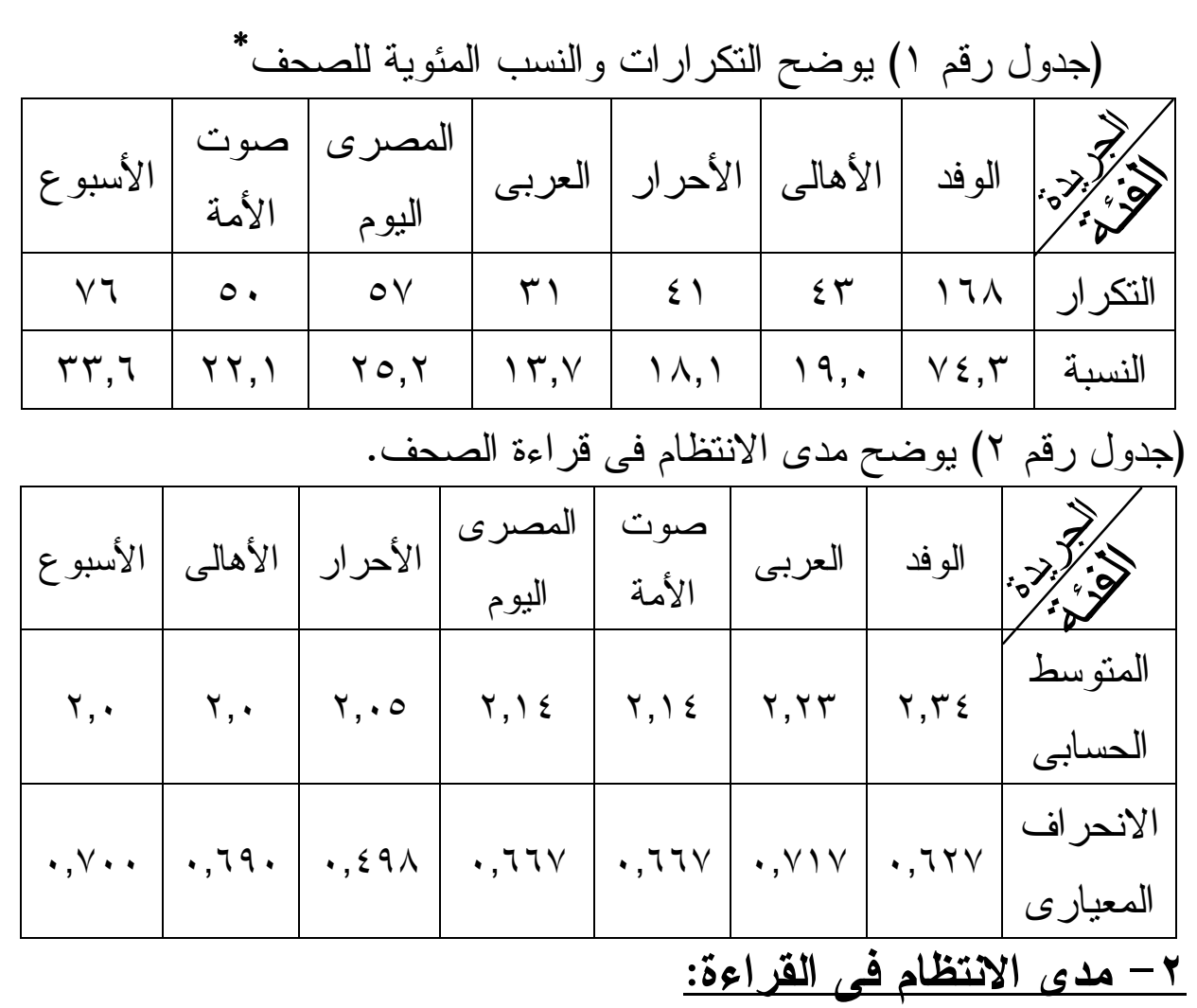

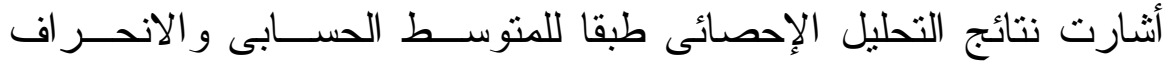

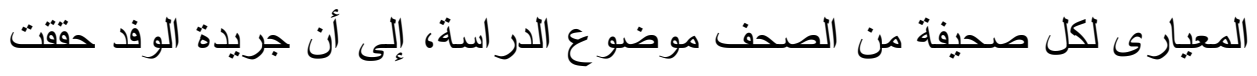

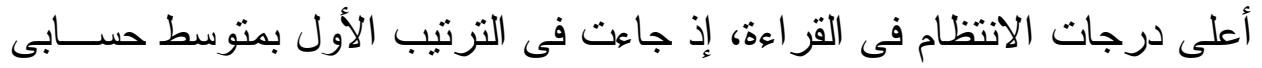

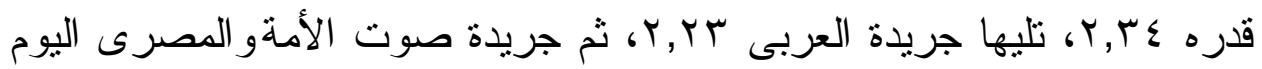

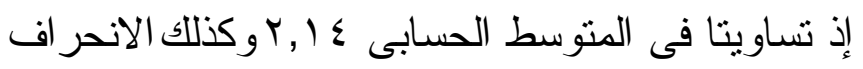

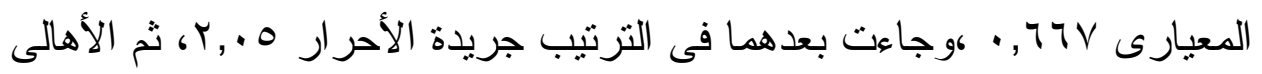

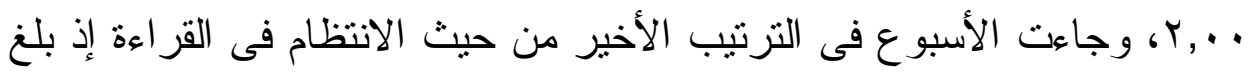

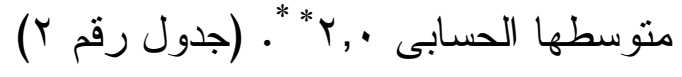




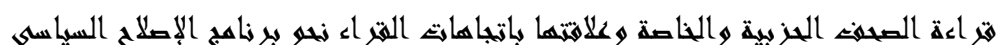

\section{ب- الوقت الأى بقضبه المبحوث فيى القراعة:}

أثنت التحليل الإحصائى ارتفاع المتوسط الحسابى لجريدة العربى من حيث

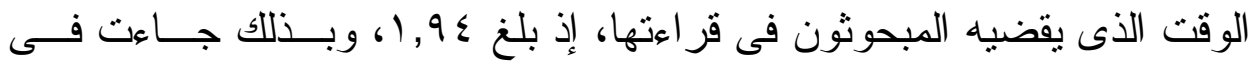

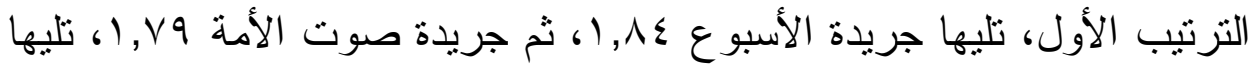

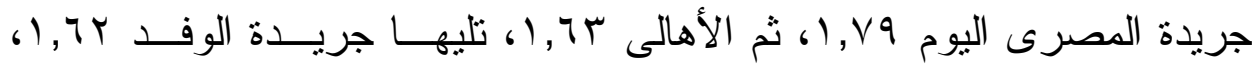

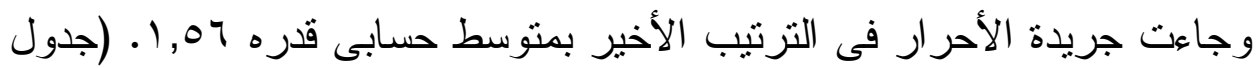

\section{ع - نمط قر اعة الصحف الحزيبة والخاصة:}

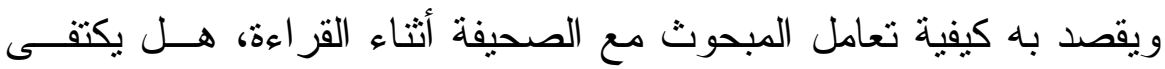

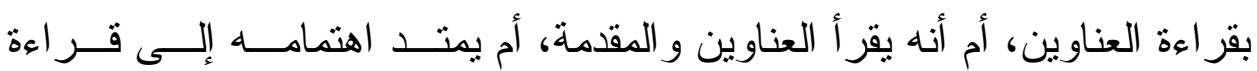

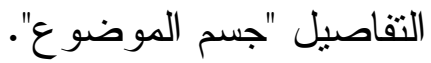

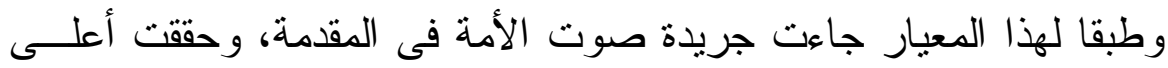

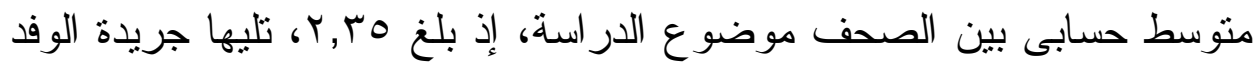

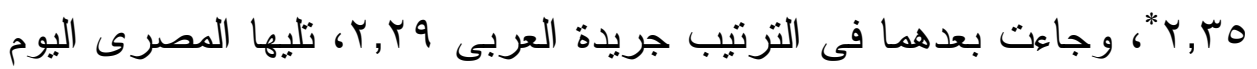

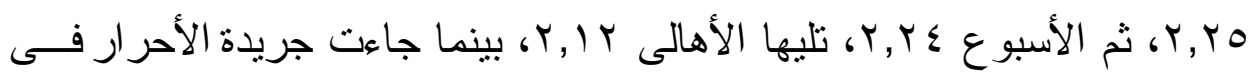

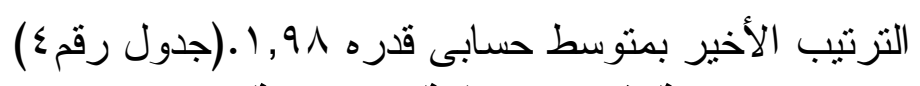
ه- مدى الثقة فحى مصداقية الصحيفة:

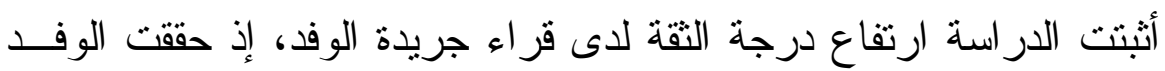

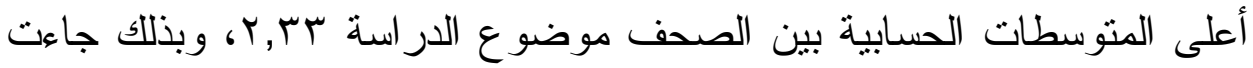

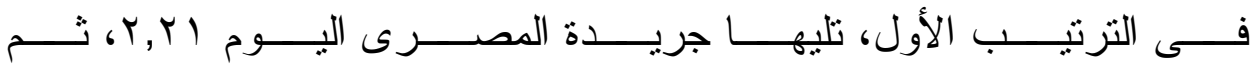




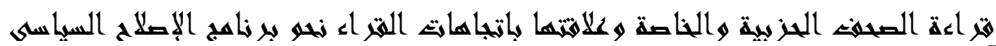

(جدول رقم ץ) يوضح منوسط الوقت الذى يقضيه المبحوثثن فى قر اءة الصحف

\begin{tabular}{|c|c|c|c|c|c|c|c|}
\hline \multicolumn{8}{|c|}{ الحزبية و الخاصة. } \\
\hline الأحر ار & الوفد ل & الأهالى & اليوم اليوى & صوت الأمة & الأسبوع & العربى & 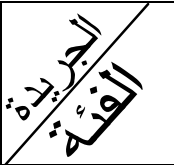 \\
\hline 1,07 & $1,7 r$ & $1, \pi$ & 1,19 & $1, \times 9$ & $1, \wedge \varepsilon$ & $1,9 \varepsilon$ & الحستوسط \\
\hline$\cdot, v \cdot 9$ & $\cdot, \times 17$ & $\cdot, V Y O$ & $\cdot, \wedge \Gamma \wedge$ & •, Vo. & $\cdot$, , 74 & $\cdot, 7 \Lambda$. & الالتعبارى \\
\hline
\end{tabular}

(جدول رقمع) يوضح نمط قر اءة الصحف الحزبية و الخاصة لدى المبحوثين.

\begin{tabular}{|c|c|c|c|c|c|c|c|}
\hline الأحر ار & الأهالى & الأسبوع & اليصرى & العربى & الوفد & صوت الأمة & 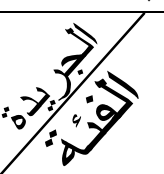 \\
\hline 1,91 & $r, Y r$ & T \{ & Y,YO & $r, r q$ & r, ro & r, ro & الحسابى \\
\hline$\cdot, \vee \circ \wedge$ & • & $\cdot, \wedge \leqslant \vee$ & 10. & r & $\cdot, v \cdot q$ & $\cdot, 79 \leq$ & الالانحر اف \\
\hline
\end{tabular}

(جدول رقم ه)يوضح مدى ثقة القر اء فيما تكتبه الصحف عن الإصلاح السياسى.

\begin{tabular}{|c|c|c|c|c|c|c|c|}
\hline الأحر ار & الأهالى & الأسبوع & العربى & صوت الأمة & اليوم اليور & الوفد & $=\frac{7}{4}: \frac{1}{4}: \frac{0}{0}$ \\
\hline 1,91 & $r, \cdot V$ & $r, 1$. & $r, 1$. & $r, \mid \Lambda$ & $r, Y$, & r, & الحسابى \\
\hline$\cdot, \Sigma) \wedge$ & $\cdot, 0 \cdot V$ & $\cdot, 0 \wedge$. & 9 & . & . & . OYT & الالنحر اف \\
\hline
\end{tabular}




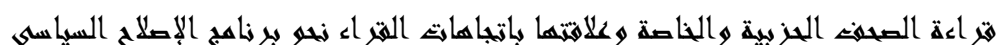

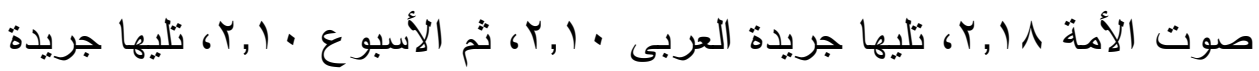
الأهالى V · , r، وجاءت جريدة الأحر ار فى الترتيب الأخير بمتوسط حسابى قدره

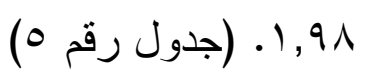

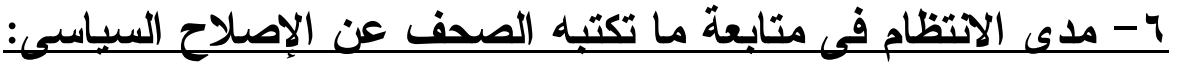
أثبتت الدر اسة أن قر اء جريدة الوفد حققو أعلى درجات الانتظام فى متابعة ما تكتبه الوفد عن الإصلاح السياسى، مقارنة بقر اء الصحف الأخــرى، وبـــللك جاءت الوفد فى الترتيب الأول بمتوسط حسابى قدره بr,r، تليها جريدة العربى

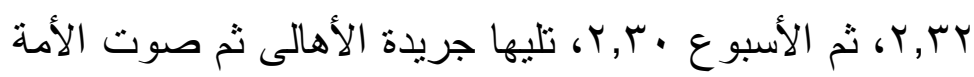
بمنوسط حسابى قدره Y, I, لكل منهما، وجاءت بعدهما جريدة المصرى اليــوم ع ا, Y، ثم الأحر ار التى جاءت فى التزتيب الأخير بمتوسط حسابى قدره • I, I.

$$
\text { (جدول رقم }
$$

V - مدى موضوعية الصحف فحى عرض قضبة الإصلاح السباسيى:

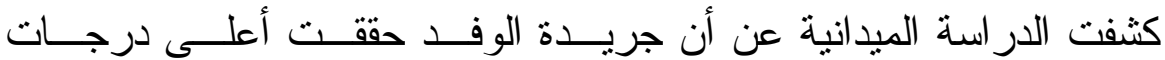
الموضوعية فيما كتبته عن الإصلاح السياسى، وذلك من وجهة نظر أفر اد العينة،

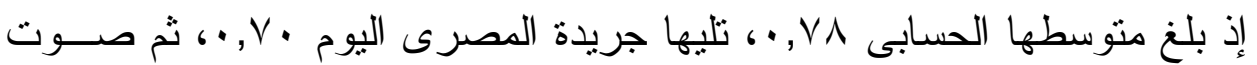

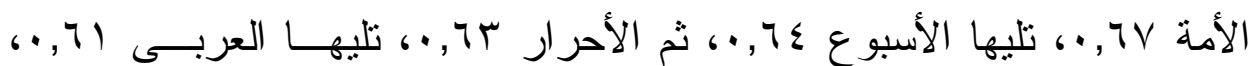

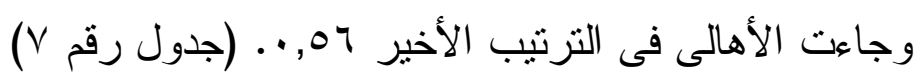

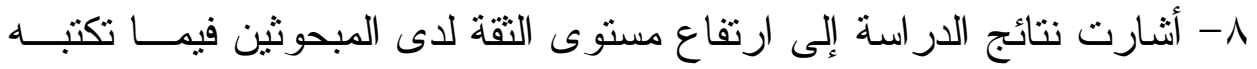

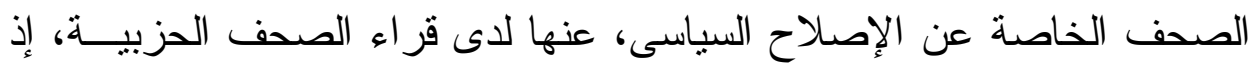

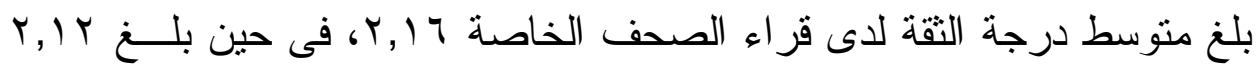
لدى قراء الصحف الحزبية. من ناحية أخرى أوضحت الدر اسة أن قر اء الصحف الخاصة يقضون وقتا

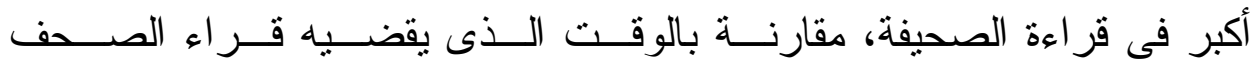




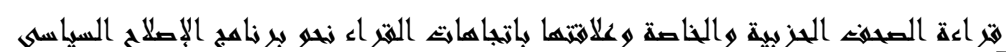

(جدول رقم T) يوضح مدى الانظام فى متابعة ما تكتبه الصحف عن الإصلاح

\begin{tabular}{|c|c|c|c|c|c|c|c|}
\hline الأحر ار & اليور اليصرى & صوت الأمة & الأهالى & الأسبوع & العربى & الوفد & $07.37:-\frac{1}{4}$ \\
\hline$r, 1$. & $r, 1 \varepsilon$ & $r, 17$ & $r, 17$ & $r, r$. & r,rr & T, MT & الحسابى \\
\hline . & $\cdot, \vee \vee T I$ & , , Y01 & $\cdot, \neg \wedge \wedge$ & • & $\cdot, V \cdot r$ & $\cdot, 7.9$ & الالمعيارى \\
\hline
\end{tabular}

(جدول رقم V) يوضح رؤية المبحوثين الصحفية للإصلاح السياسى .

\begin{tabular}{|c|c|c|c|c|c|c|c|}
\hline 'هالى & العربى & الأحر ا ر & الأسبو & صوت & ى اليوم & الوفد & $=0.7 \%: \frac{3}{4}$ \\
\hline 1,91 & $r, I r$ & $r, Y \leqslant$ & r, ro & $r, r q$ & r, ro & $r, r_{0}$ & الحسابى \\
\hline $\begin{array}{c}\cdot, \text { vo } \\
\wedge\end{array}$ & $\begin{array}{c}\cdot, V T \\
1\end{array}$ & $\cdot, \wedge \leqslant \vee$ & •, ^०. & $\begin{array}{c}\cdot, 79 \\
r\end{array}$ & $\cdot, v \cdot q$ & $\begin{array}{c}\cdot, 79 \\
\varepsilon\end{array}$ & الالنحر اف \\
\hline
\end{tabular}

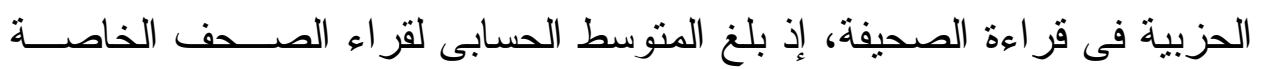

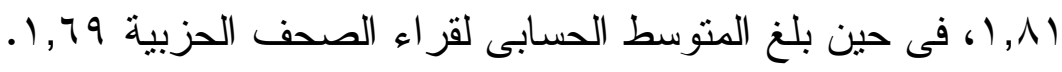

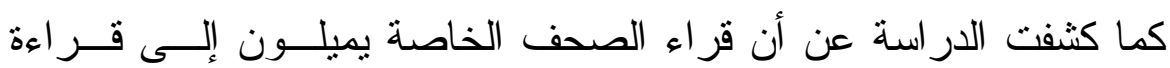

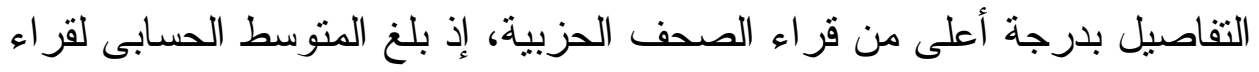

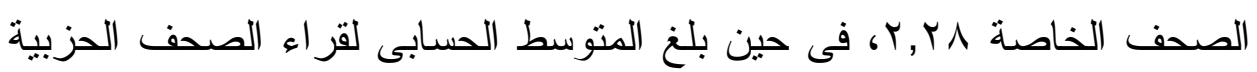




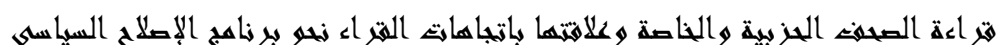

أما عن رؤية المبحوثين لمدى موضو عية الصحف فـى عــرض قضــية

الإصلاح السياسى فقد أثنارت نتائج الدراسة إلى أن المبحوثون يذهبون إلـى أن الصحف الخاصة كانت أكثر موضوعية فى عرضها لقضية الإصـلاح السياسـى من الصحف الحزبية، ويمكن تفسير ذلك بأن الجريدة الخاصة تعرض وجهــات النظر المؤيدة و المعارضة حول القضايا التى تطرحها، بينما تحــرص الجريــدة الحزبية على تقديم وجهات النظر و الآر اء المؤيدة لرؤية الحزب الذى تعبر عنــهـ الجريدة الحزبية، إذ بلغ المتوسط الحسابى لقراء الصحف الخاصة لاT, •، فـى حين بلغ المتوسط الحسابى لقر اء الصحف الحزبية ه7 , . . بينما أثنارت الدر اسة إلى أن قر اء الصحف الحزبية حققو الدرجة أعلى من حيث الانتظام فى متابعة ما تكتبه هذه الصحف عن الإصلاح السياسى، مقارنـــة

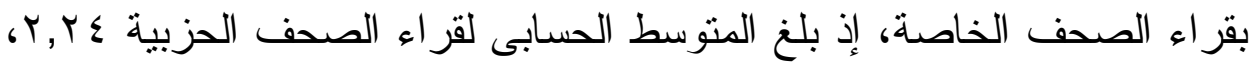
فى حين بلغ المتوسط الحسابى لقر اء الصحف الخاصة . r, r. . وقد تساوت الصحف الحزبية و الخاصة من حيث مدى الانتظام فى القر اءة

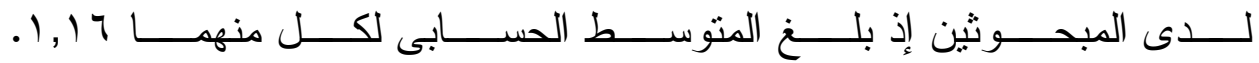

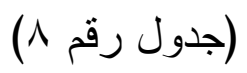
ب: النتائج التى تتعلق بالعلاقة بين قراءة الصحف الحزيبة والخاصة والاتجاه نحو الإصلاح السياسي: مقاييس الار اسة: لمعرفة العلاقة بين العلاقة بين قر اعة الصحف الحزبية و الخاصة وبــين اتجــاه القر اء نحو برنامج حكومى للإصلاح السياسى، اعتمدت الدر اسة على مقياسـين هما:

$$
\begin{aligned}
& \text { r) الاتجاه } \\
& \text { ( ) معدل القر اءة }
\end{aligned}
$$




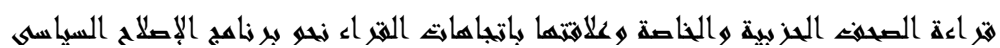

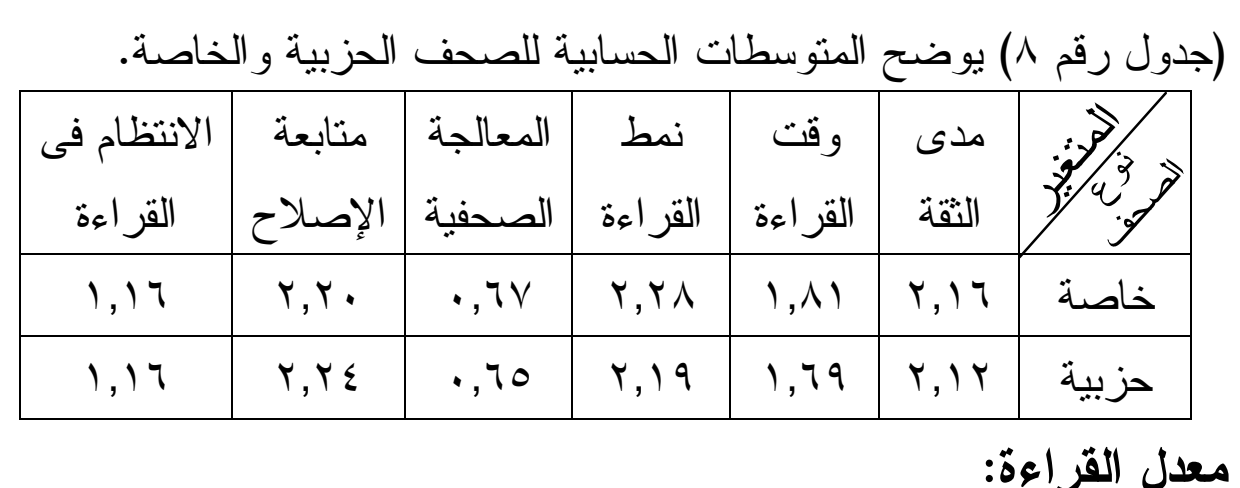

وضع الباحث مقياساً لتحديد معدل قر اعة الصحف الحزبية و الخاصة لدى أفــراد

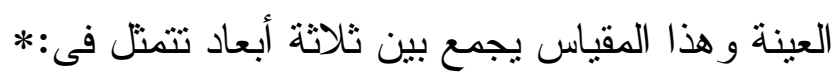
1- مدى الانتظام فى قر اءة الصحف الحزبية و الخاصة.

r- الوقت الذى يقضيه المبحوث فى قر اعة الصحف الحزبية و الخاصة. ب- نمط القر اعة أى كيفية قر اهة الصحيفة، هل يقر أ عناوينها فقـــ أم يقــر أ العناوين و المقدمة أم يقر أ العناوين و المقدمة و التفاصيل. يتكون هذا المقباس من تشع درجات، تنقسم إلحى ثلاث مستوبيات همى:

$$
\begin{aligned}
& 1 \text { - معدل قر اعة منخفضة من ب: ـ درجات } \\
& \text { Y- معدل قر اعة متوسط من } 0 \text { : V درجات } \\
& \text { r- معدل قر اعة مرتفع من ^م: } 9 \text { درجات }
\end{aligned}
$$

وطقا لهزا المقباس كشف التحليل الإحصائى عن النتائج التالية:

ا- أن معدل قر اعة الصحف الحزبية والخاصة لدى أفر اد العينة هو معــدل متوسط، ففى جريدة الوفد بلغت نسبة الذين حققو ا معدل قر اعة متوســـ

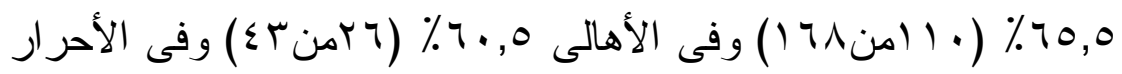

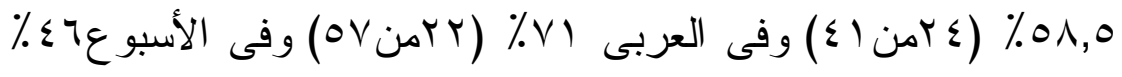

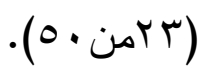




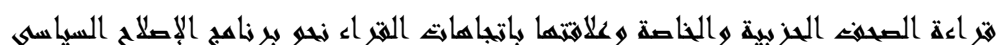

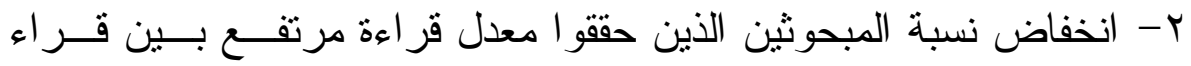

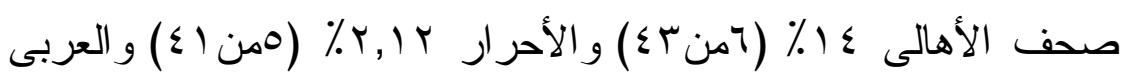

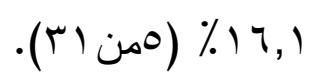

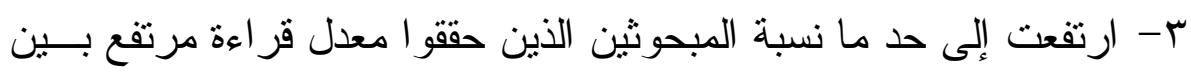

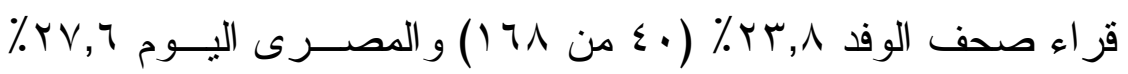

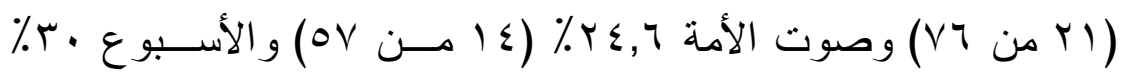
(0. 10 )

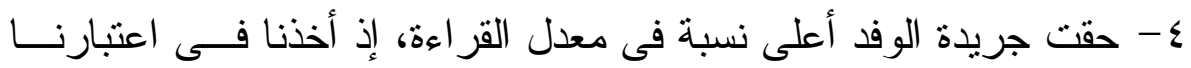

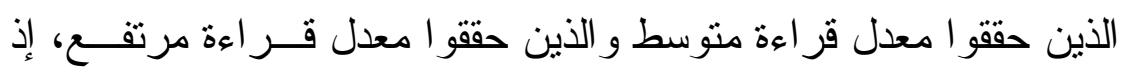

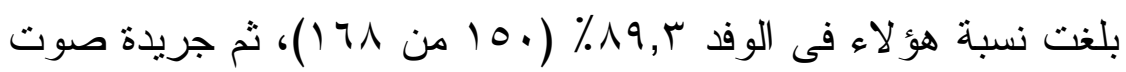

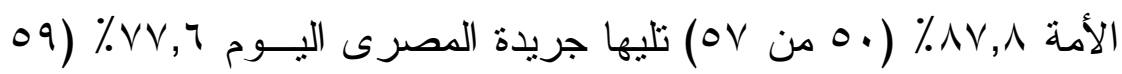

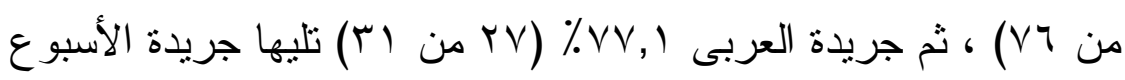

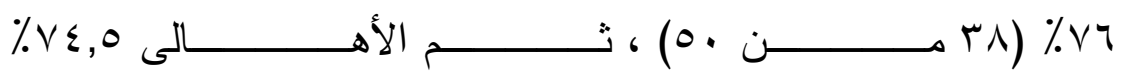

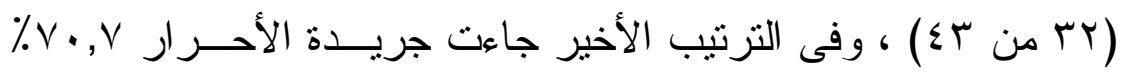

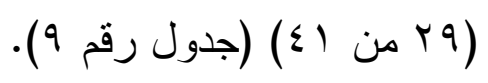

ب- مقياس الاتجاه:

اعتمدت الدر اسة على مقياس ليكرت Likert لحساب درجة الاتجاه، ومن ثم

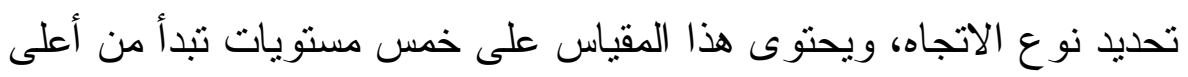

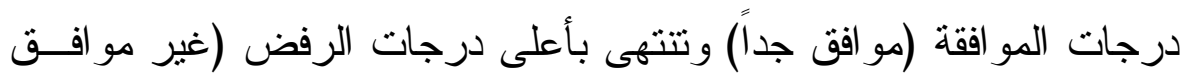

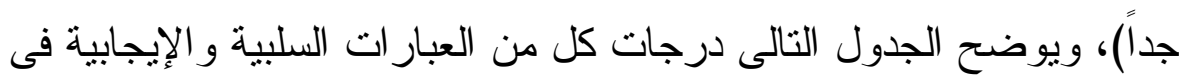
كل مستوى من مستويات المقياس: 


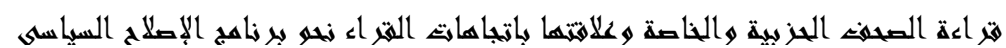

\begin{tabular}{|c|c|c|c|c|c|}
\hline \multicolumn{6}{|c|}{ درجات العبار ات السلبية و الإيجابية و المحابدة على مقياس الاتجاه } \\
\hline غير مو افق & غير مو افق & محابد & مو افق & مو افق جداً & \\
\hline 1 & r & r r ( ب & $\varepsilon$ & 0 & إيجابية \\
\hline 0 & $\varepsilon$ & r & $r$ & 1 & سلبية \\
\hline
\end{tabular}

(جدول رقم 9) يوضح معدل التعرض للصحف الحزبية و الخاصة.

\begin{tabular}{|c|c|c|c|c|c|c|c|c|c|c|c|c|c|c|}
\hline \multicolumn{2}{|c|}{ الأسبوع } & \multicolumn{2}{|c|}{ صوت الأمة } & \multicolumn{2}{|c|}{ اليصرى اليوم } & \multicolumn{2}{|c|}{ العربى } & \multicolumn{2}{|c|}{ الأحر ار } & \multicolumn{2}{|c|}{ الأهالى } & \multicolumn{2}{|c|}{ الوفد } & \\
\hline$\%$ & ك & $\%$ & ك5 & $\%$ & ك5 & $\%$ & ك5 & $\%$ & ك5 & $\%$ & ك & $\%$ & ك & \\
\hline$r \varepsilon,$. & IT & Ir,r & V & $T Y, \varepsilon$ & IV & $1 T, 9$ & $\varepsilon$ & $r q, r$ & IT & $Y_{0, T}$ & 11 & $1 \cdot, v$ & 11 & منخفض \\
\hline$\leq 7$, & Tr & Tr, & ru & $0 ., \cdot$ & rᄉ & $\times 1, \cdot$ & rr & $0 \wedge, 0$ & $r \varepsilon$ & $7 ., 0$ & rT & 70,0 & 11. & متوسط \\
\hline$r \cdot, \cdot$ & 10 & $r \varepsilon, T$ & $1 \varepsilon$ & $r V, T$ & YI & 17,1 & 0 & $M, r$ & 0 & $1 \leqslant,$. & 7 & $r r, \Lambda$ & $\varepsilon$. & مرتفع \\
\hline $1 \ldots$ & 0. & $1 \ldots$ & ov & $1 \ldots$ & $V T$ & $1 \ldots$ & $M$ & $1 \ldots$ & $\varepsilon 1$ & $1 \ldots$ & $\varepsilon r$ & $1 \ldots$ & 171 & المجموع \\
\hline
\end{tabular}

وفى ضوء هذا المقياس تم حساب وتحديد نوع اتجاه المبحــوثين نحسـو الإصلاح السياسى على النحو التالى:

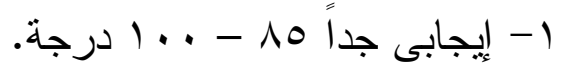

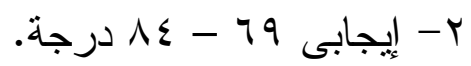

$$
\begin{aligned}
& \text { r - كحايد }
\end{aligned}
$$

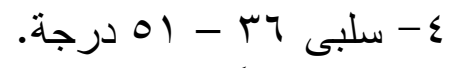

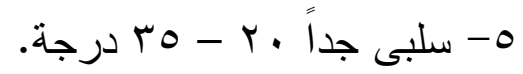

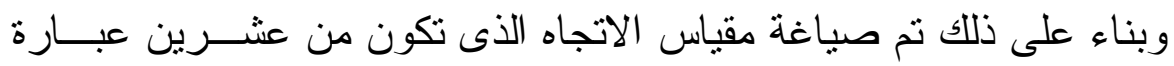

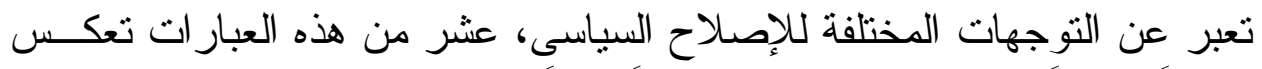

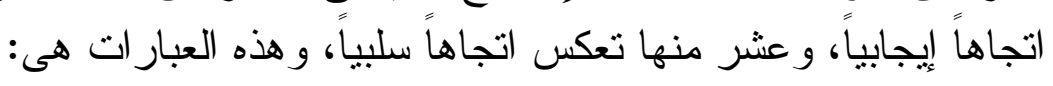
( ) الحكومة غير جادة فى تحقيق الإصلاح السياسى.

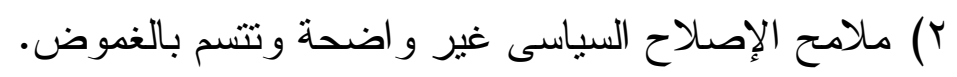

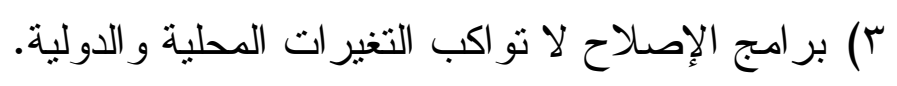




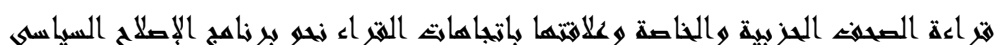

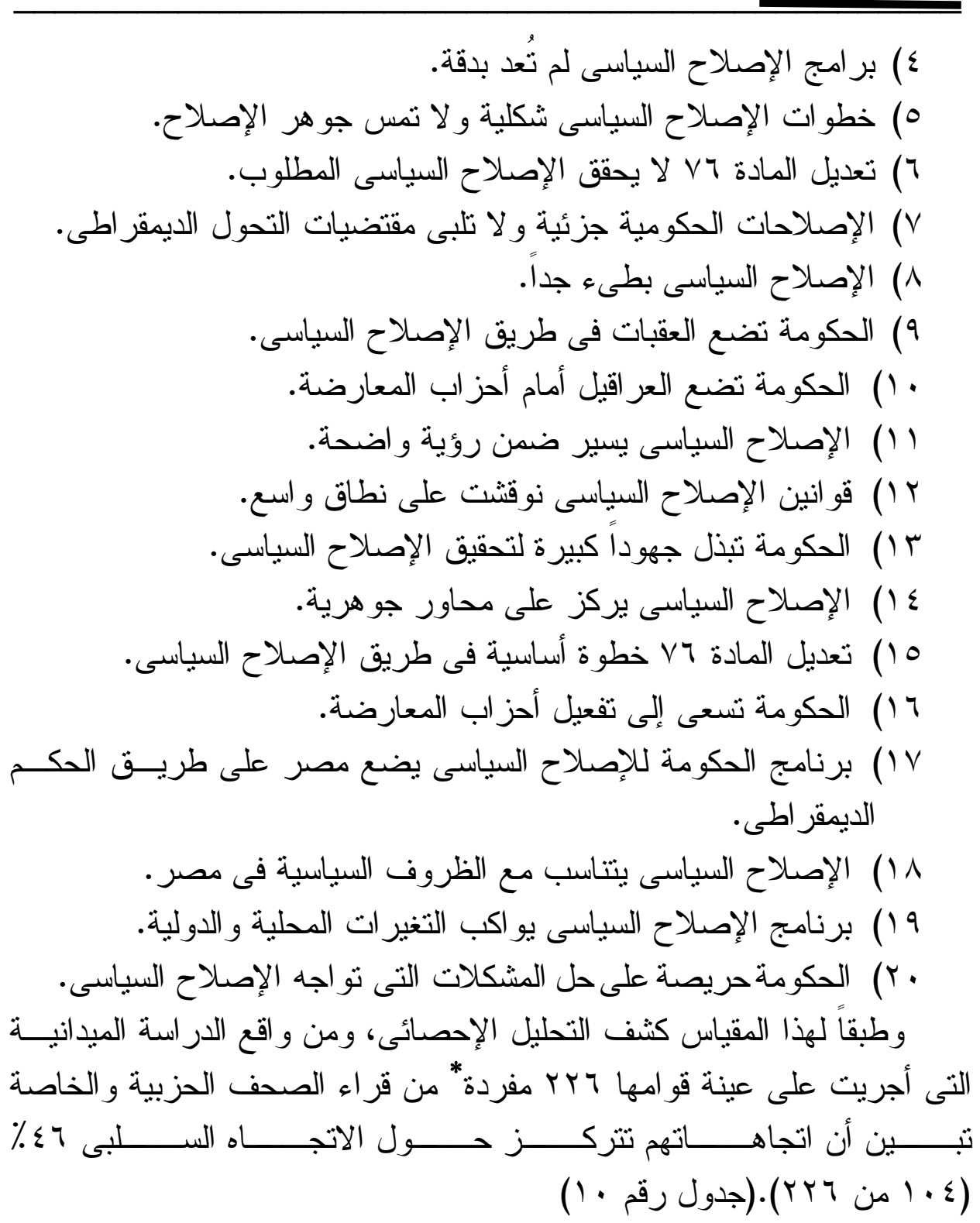

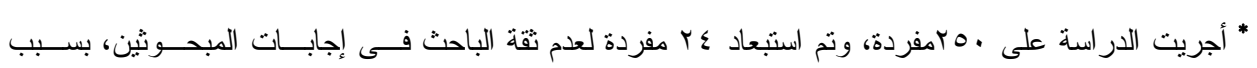

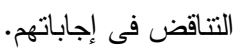




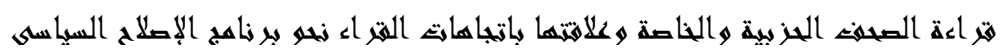

(جدول رقم · (1) يوضح اتجاه قر اء الصحف الحزبية و الخاصة نحو الإصــلاح

\begin{tabular}{|c|c|c|c|c|c|c|}
\hline المجموع & سلبى جداً & سلبى & محايد & إيجابى & $\begin{array}{c}\text { إيجابِى } \\
\text { حداً }\end{array}$ & $0 \%: \frac{1}{0}$ \\
\hline TrT & $\varepsilon r$ & Tr & $7 \leq$ & $\varepsilon r$ & 10 & التكر ار \\
\hline$\% 1 \ldots$ & $\% \backslash \wedge, 7$ & $\%$ YV, $\Sigma$ & $\%$ \%^,r & $\% 19$, & $\% 7,7$ & النسبة \\
\hline
\end{tabular}

وبناء على ما سبق يمكن القول أن أفر اد العينة يرتفع بينهم الاتجاه الســلبى

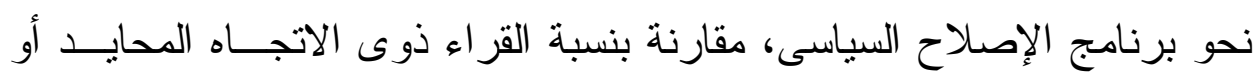
الإيجابیى.

أولاً: العلاقة بين معدل القراعة والاتحاه نحو الإصلاح السباسىى:

باستخدام معامل ارتباط بيرسون Pearson Correlation، لمعرفة العلاقة بين معدل القر اءة وبين اتجاه القر اء نحو الإصلاح السياســى، أثبـــت التحليـلـل الإحصائى ما يلى : إنى

ا- توجد علاقة ارتباط دالة إحصائياً بين معدل قر اعة جريدة الوفــــ وبـين

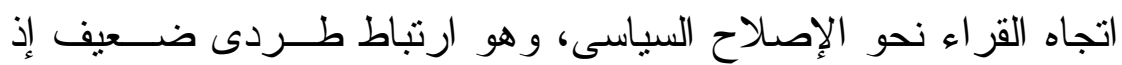

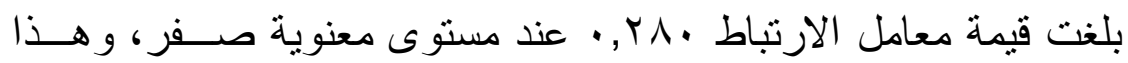
يعنى أن زيادة تعرض أفر اد العينة لجريدة الوفد يصاحبه زيادة فى ميل الأفر اد إلى الاتجاه الإيجابى نحو الإصلاح السياسى. r- توجد علاقة ارتباط دالة إحصائياً بين معدل قر اءة جريدة الأهالى، وبين اتجاه قراء الجريدة نحو الإصلاح السياسى، وهو ارتباط عكسى متوسط

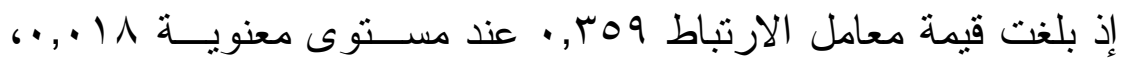

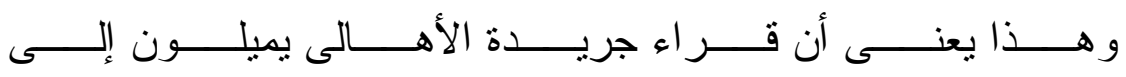




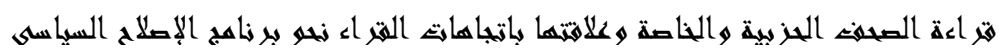

الاتجاه السلبى نحو الإصلاح السياسى كلما زاد معدل نعرضهم لجريــة

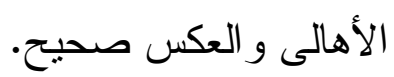

r- نوجد علاقة ارتباط دالة إحصائياً بين معدل قر اءة جريدة الأحر ار ، وبين

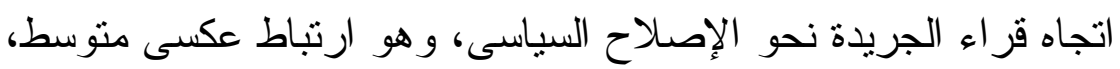

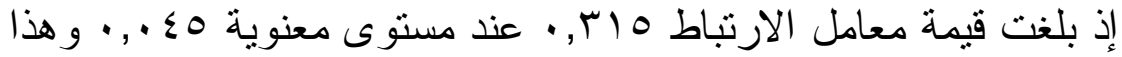
يعنى أن قراء جريدة الأحر ار يميلون إلى الاتجاه السلبى نحو الإصلاح السياسى، كلما ز اد معدل تعرضهم للجريدة.

ع- نوجد علاقة ارتباط دالة إحصائياً بين معدل قر اءة جريدة لإدة العربى، وبين اتجاه قراء الجريدة نحو الإصلاح السياسى، هو ارتباط عكسى منوسط،

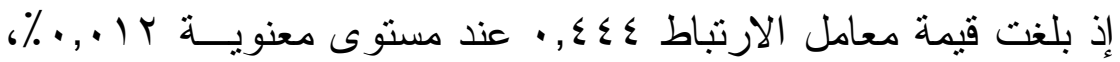

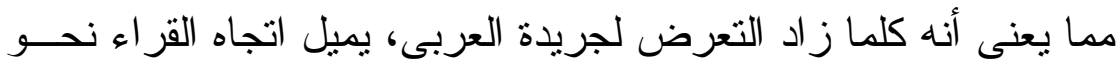

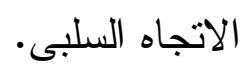
ه- نوجد علاقة دالة إحصائياً بين معدل قراءة جريدة المصرى البوم، وبين

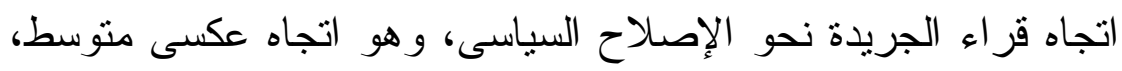

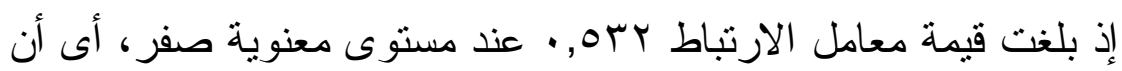

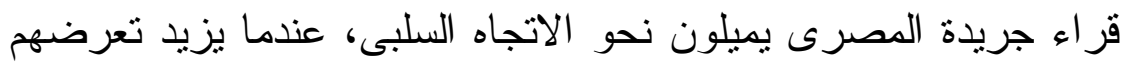
للجريدة. 1- توجد علاقة ارتبــاط دالــة إحصــائياً بــين معـدل قــر اعة جريــدة

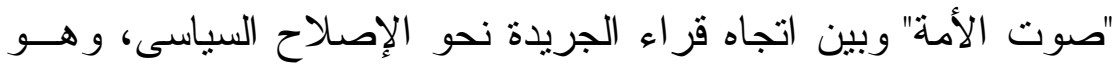

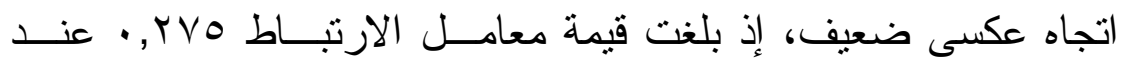

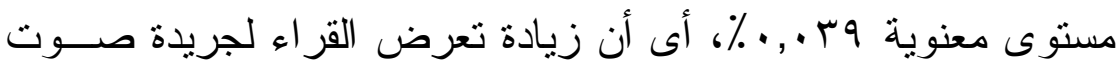

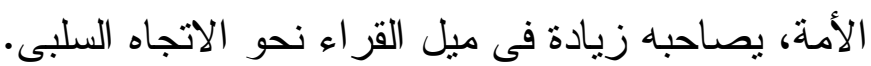




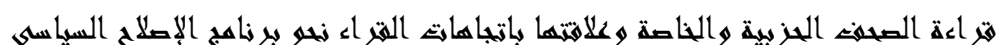

(جدول رقم 1) (1) يوضح العلاقة بين معدل القراءة، والاتجــاه نحــو الإصــلاح

\begin{tabular}{|c|c|c|c|c|c|c|c|}
\hline الأسبوع & صوت الأمة & المصرى & العربى & الأحر ار & الأهالى & الوفد & \\
\hline$\cdot, 0.0$ & - YYO & אי, • & $\cdot, \leq \leqslant \leq$ & هוץ, • & q & $\cdot$, r $\wedge$. & الارنباط \\
\hline$\cdot, \cdots$ & $\cdot, \cdot r q$ & $\cdot, \cdots$ & $\cdot, \cdot, T$ & $\cdot, \cdot \leq 0$ & $\cdot, \cdot 11$ & $\cdot, \ldots$ & المعنوية \\
\hline
\end{tabular}

- توجد علاقة ارتباط دالة إحصائياً بين معدل قر اعة جريدة "الأسبوع" وبين اتجاه قراء الجريدة نحو الإصلاح السياسى، وهو اتجاه عكسى متوسط،

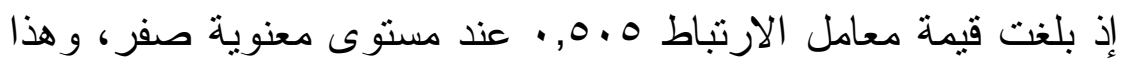

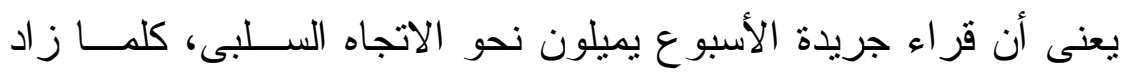

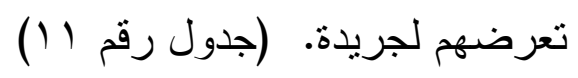

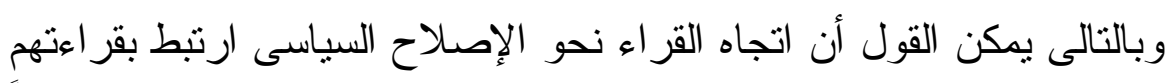

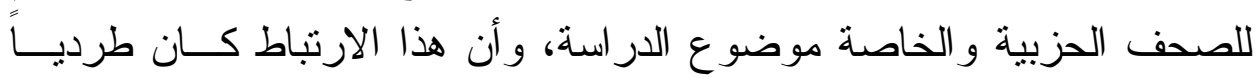

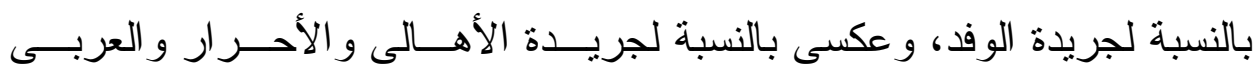

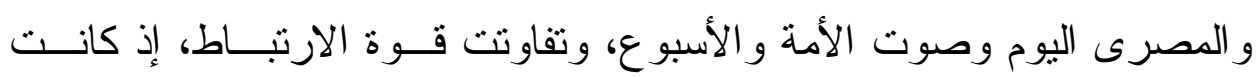

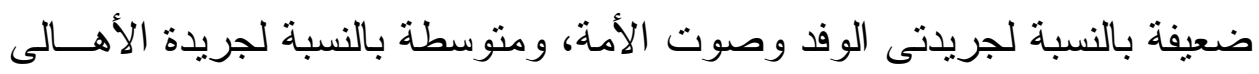

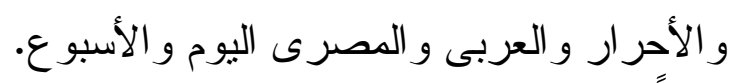

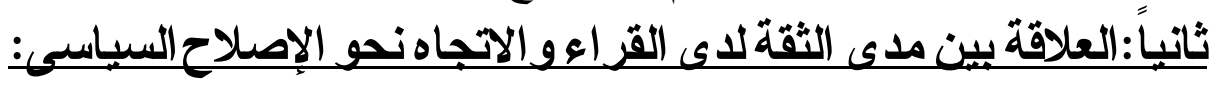
باستخدام معامل ارتباط بيرسون Pearson Correlation لمعرفة العلاقة بين مدى الثقة لدى القر اء فى الصحف الحزبية و الخاصة موضـــوع الدر اســـة وبين اتجاههم نحو الإصلاح السياسى، أثبت التحليل الإحصائى ما يلى: 


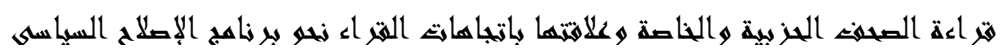

ا- توجد علاقة ارنباط دالة إحصائياً بين مستوى ثقة القر اء فى جريدة الوفد

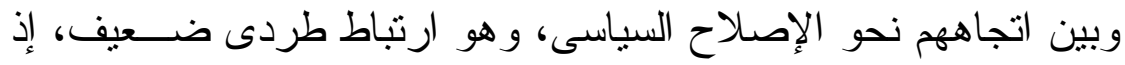

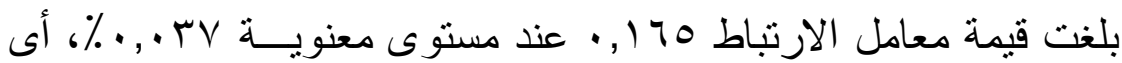

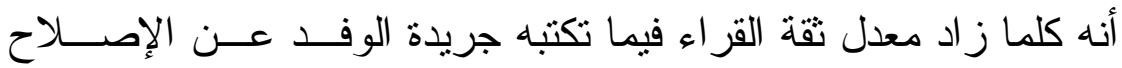

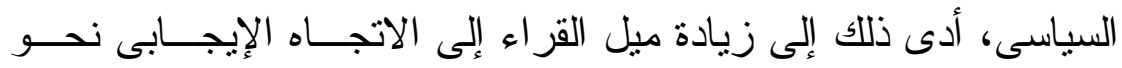
الإصلاح السياسى. ץ- توجد علاقة ارتباط دالة إحصائياً بين مستوى ثقة قر اء جريدة المصرى اليوم وبين اتجاههم نحو الإصلاح السياسى، أما نوع العلاقة فهى عكسية

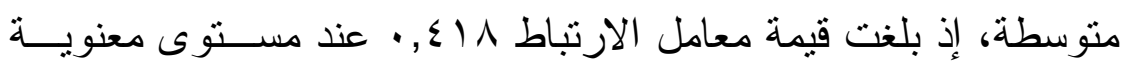
• مفر ب- توجد علاقة ارتباط دالة إحصائيا بين مستوى ثقة قر اء جريدة الأســبوع

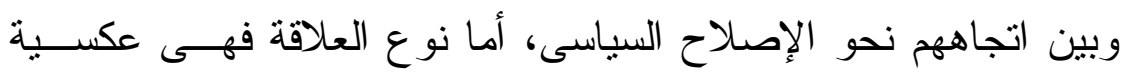

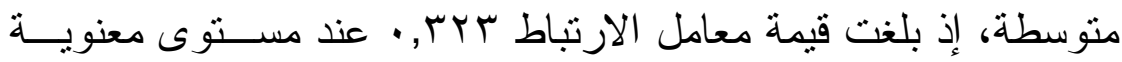
r r • , • \%، و هذا يعنى أن زيادة ثقة قر اء جريــدتى المصــرى اليــوم

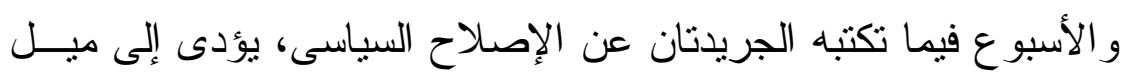
قر اء الجريدتين إلى الاتجاه السلبى نحو الإصـلاح السياسى.

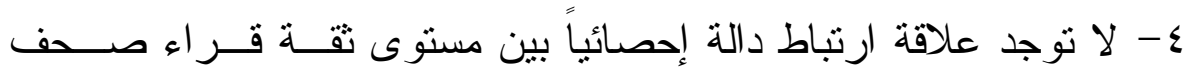
الأهالى و الأحر ار و العربى وصوت الأمة وبين اتجاههم نحو الإصــلاح

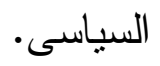
وبالتالى يمكن القول أن اتجاه القراء نحو الإصلاح السياسى ارتبط بـــدى ثقة القر اء فى صحف الوفد و المصرى اليوم و الأسبوع، فإن هذا الارنباط كــان

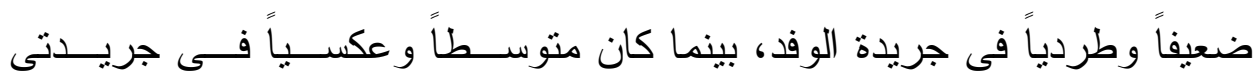

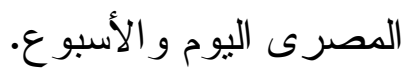




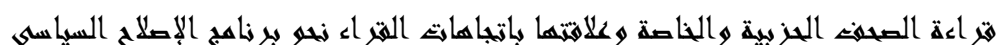

(جدول رقم r ( ) يوضح العلاقة بين مستوى الثقة لدى القر اء وبين اتجاههم

\begin{tabular}{|c|c|c|c|c|c|c|c|}
\hline & & & & & & & الإصا \\
\hline الأسبو ع & صوت الأمة & اليومرى & العربى & الأحر ار & الأهالى & الوفد & \\
\hline سTr, & $\cdot, r Y \wedge$ & $\cdot, \leqslant \backslash \wedge$ & r, & $\cdot, 191$ & $\cdot, \cdot r V$ & $\cdot 170$ & الارنباط \\
\hline$\cdot, \cdot r r$ & $\cdot, \cdot \wedge \wedge$ & $\cdot, \cdots$ & $\cdot, \Gamma \wedge \varepsilon$ & $\cdot, Y \backslash \leqslant$ & $\cdot, \Lambda \backslash Y$ & $\cdot, \cdot T V$ & المعنوية \\
\hline
\end{tabular}

من ناحية أخرى انتقت العلاقة بين مستوى الثقة لاى القر اءو واتجاههم نحو

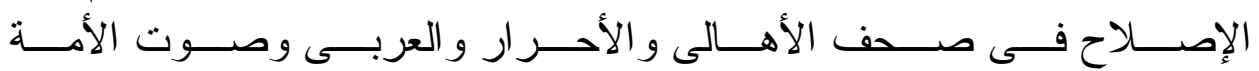

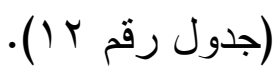

ثالثاً:العلاقة بين مدى موضوعية الصحفية والاتجاه نحو الإصلاح السياسيح:

باستخدام معامل ارتباط بيرسون Pearson Correlation لمعرفة العلاقة بين مدى موضوعية الصحفية فى عرض قضية الإصـــلاح السياسـىى، وبــين

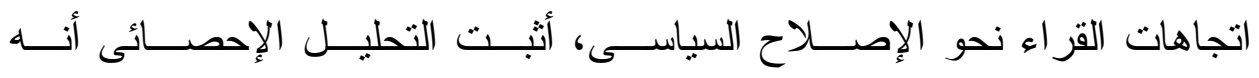

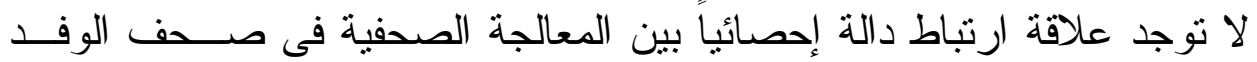

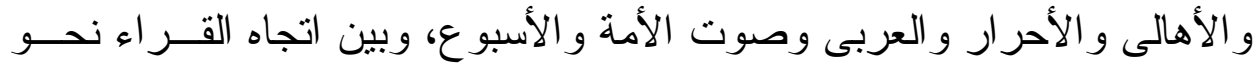

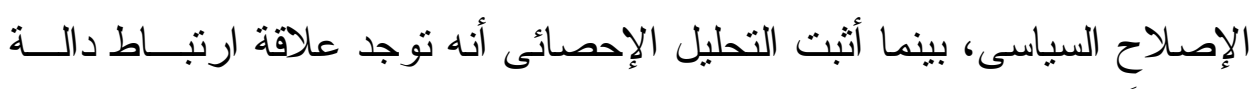
إحصائياً بين مدى موضو عية صحفية "المصرى اليوم" فــى عرضــــها لقضــية الإصلاح السياسى، وبين اتجاهات قر اء الجريدة نحو الإصـلاح السياسى، وهـــ

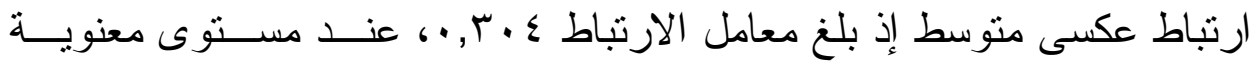

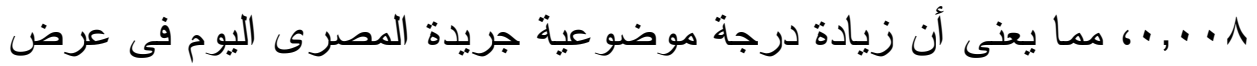
قضية الإصلاح السياسى، يصاحبه ميل القراء إلى الاتجاه السلبى نحو الإصلاح

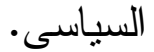




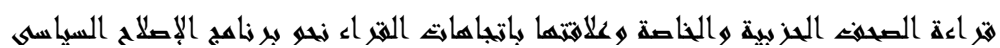

وبالتالى يمكن القول أن اتجاه قر اء جريدة المصرى نحو الإصلاح السياسى

ارتبط بمدى موضو عيتها فى عرض القضية. (جدول رقم ب I)

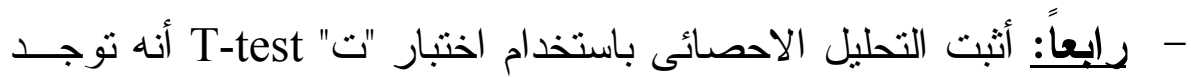

فروق ذات دلالة إحصائية بين الذكور و الإناث من قر اء جريدتى الوفـــ

و المصرى اليوم وذللك فيما يتعلق بمعدل القراعة، إذ بلغت قيمة "ت" فـى

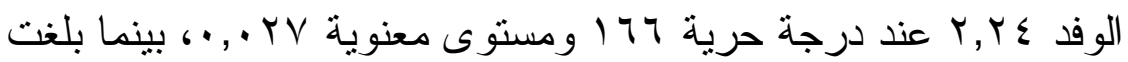

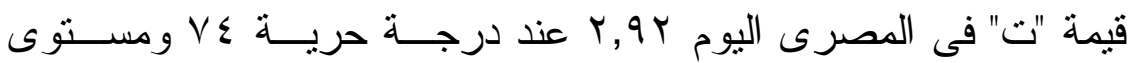

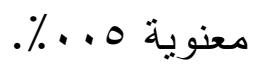

وبقر اءة المتوسط الحسابى لكل من الأكور و الإناث من قر اء الجريدتين، يتضح أن المتوسط الحسابى للأكور أعلى منه لدى الإناث، وبذلك يمكن القول أن الذكور من قر اء الجريدتين حقق ا معدل قر اءة أعلى من الإناث. - أثثبت التحليل الإحصائى باستخدام اختبار "ت" T-test أنه لا توجد فروق ذات دلالة إحصائية بين الذكور و الإناث من المبحوثين وذلك فيما يتعلق باتجاههم نحو الإصلاح السياسى. one way - كذلك أثنبت التحليل الإحصائى باســتخدام تحليـلـل التبــاين أنه لا توجد فروق ذات دلالة احصائية بين المستويات التعليمية المختلفة للمبحوثين، وذللك فيما يتعلق باتجاههم نحو الإصلاح السياسـى، أيضا أثبت التحليل أنه لا توجد فروق ذات دلالة إحصائية بين مستويات الدخل المختلفة للمبحوثين فيما يتعلق باتجاههم نحو الإصـلاح السياسـى. كما أثبت التحليل الاحصائى أنه لا توجد فروق ذات دلالة إحصائية بين المستويات التعليمية المختلفة ومستوى الدخل لدى المبحوثين وذلك فيمــا

يتعلق بمعدل القر اءة.(جدول رقم ع ( ) 


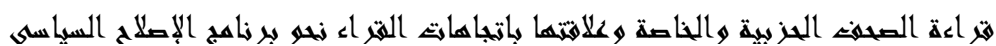

(جدول رقم r I ) يوضح العلاقة بين مدى موضوعية الصحف و اتجاهات القر اء

\begin{tabular}{|c|c|c|c|c|c|c|c|}
\hline الأسبو ع & صوت الأمة & اليور اليوم & العربى & الأحر ار & الأهالى & الوفد & \\
\hline., 19. & $\cdot, Y Y V$ & ع • & • & $\cdot, Y K I$ & $\cdot, \cdot, \varepsilon$ & .,., & الارتباط \\
\hline$\cdot, 1 \wedge V$ & $\cdot, \cdot 9$. & $\cdot, \cdots \wedge$ & $\cdot, .99$ &., 170 & $\cdot, q \mu \cdot$ & $\cdot, \wedge \leq 0$ & المعنوية \\
\hline
\end{tabular}

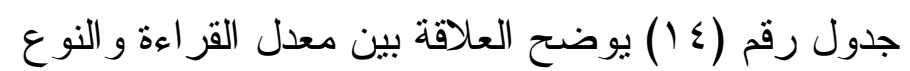

\begin{tabular}{|c|c|c|c|c|c|c|c|}
\hline المعنوية مستوى & الحرية & قيمة "ت" & الانحر افيارى & الحستوسط & العدد & النوع & \\
\hline \multirow{2}{*}{$\cdot, \cdot T V$} & \multirow{2}{*}{177} & \multirow{2}{*}{ r,Yro } & 1,001 & 7,7 . & vo & ذكر & \multirow{2}{*}{ الوفد } \\
\hline & & & $1,0 \mathrm{H} \wedge$ & $7, \cdot 7$ & 94 & أنثى & \\
\hline \multirow{2}{*}{$\cdot, Y_{l} \cdot$} & \multirow{2}{*}{$\varepsilon 1$} & \multirow{2}{*}{$1, r \vee 0$} & 1,791 & $0, \Sigma$. & $r$. & ذكر & \multirow{2}{*}{ الأهالى } \\
\hline & & & $1,7.9$ & $7, \cdot \varepsilon$ & $r \mu$ & أنثى & \\
\hline \multirow{2}{*}{$\cdot, \wedge \wedge \varepsilon$} & \multirow{2}{*}{ rq } & \multirow{2}{*}{$\cdot, 1 \leq V$} & 1,097 & $0,7 r$ & YI & ذكر & \multirow{2}{*}{ الأحر ار } \\
\hline & & & 1,190 & 0,00 & $r$. & أنتى & \\
\hline \multirow{2}{*}{$\cdot, .79$} & \multirow{2}{*}{ rq } & \multirow{2}{*}{$1, \wedge 9}$. & I,VVT & $v, \cdots$ & 10 & ذكر & \multirow{2}{*}{ العربى } \\
\hline & & & $1, r \leq$. & $0,9 \leq$ & 17 & أنثى & \\
\hline \multirow{2}{*}{$\cdot, \cdots 0$} & \multirow{2}{*}{$V \varepsilon$} & \multirow{2}{*}{$r, 917$} & $1, \wedge r \wedge$ & 7,70 & $\varepsilon \wedge$ & ذكر & \multirow{2}{*}{ اليومرى } \\
\hline & & & $1, \times \vee 1$ & 0,19 & $r \wedge$ & أنثى & \\
\hline \multirow{2}{*}{ • } & \multirow{2}{*}{00} & \multirow{2}{*}{ ו וTY, } & $1,79 \varepsilon$ & $7, .7$ & Tr & ذكر & \multirow{2}{*}{ الأمةت } \\
\hline & & & $1, \Sigma \mid T$ & 7,01 & Yร & أنتى & \\
\hline \multirow{2}{*}{$\cdot, \vee \vee \neg$} & \multirow{2}{*}{$\varepsilon \wedge$} & \multirow{2}{*}{$\cdot, Y \wedge T$} & $r, I \vee r$ & 7,17 & ro & ذكر & \multirow{2}{*}{ الأسبوع } \\
\hline & & & 1,107 & $7, \cdots$ & ro & أنتى & \\
\hline
\end{tabular}




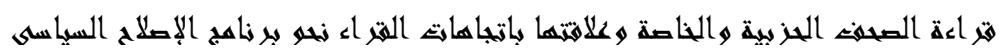

\section{النتائج العامة للار اسة}

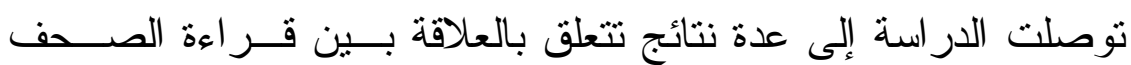

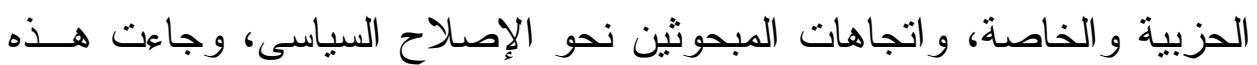
النتائج كما يلى:

ا- نوجد علاقة ارتباط دالة احصائياً بين معدل قر اءة الصـــف الحزبيــة

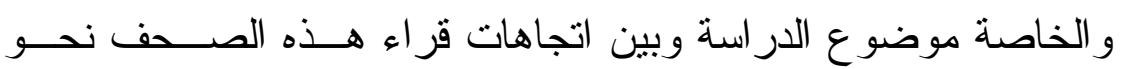

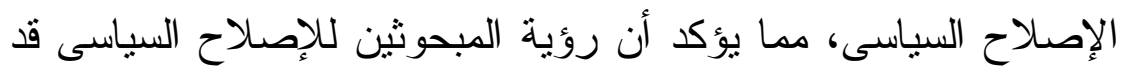
تأثرت بقر اءة الصحف الحزبية و الخاصة. r- اختلفت قوة الارتباط و اتجاهه من جريدة إلى أخرى، إذ كان الارتبـــاط

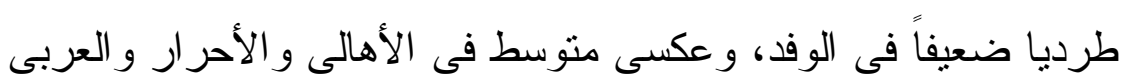

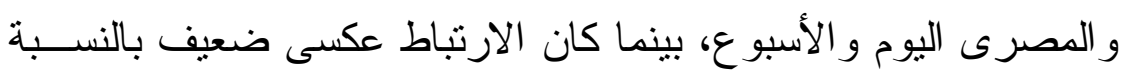

$$
\text { لجريدة صوت الأمة. }
$$

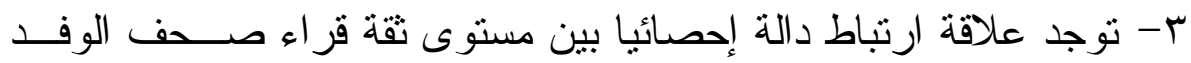

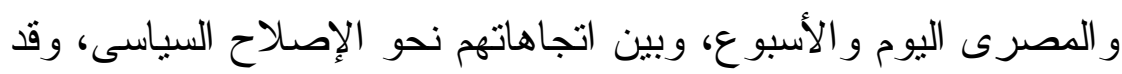

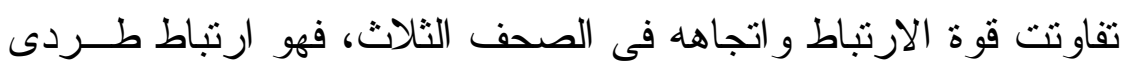
ضعيف فى الوفد، و عكسى متوسط فى المصرى اليوم و الأسبوع.

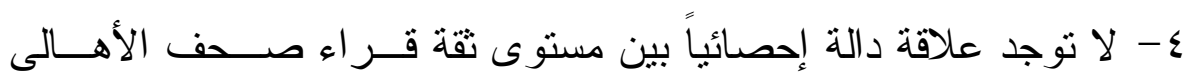

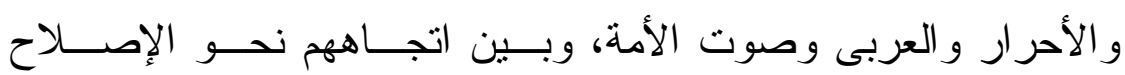

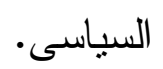
ه- نوجد علاقة ارتباط دالة إحصائياً بين المعالجة الصحفية التـى قـدمتها

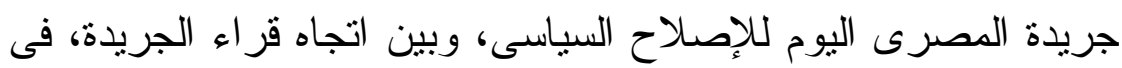

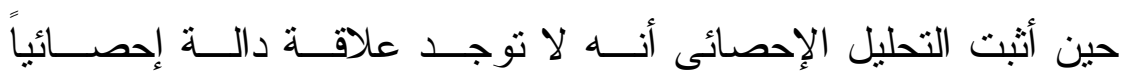




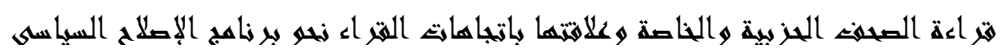

بين المعالجة الصحفية التى قدمتها صحف الوفد و الأهــالى و الأحسـرار وصوت الأمة و الأسبو ع و العربى للإصلاح السياسى، وبين اتجاه القراء.

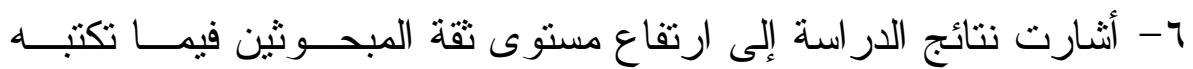

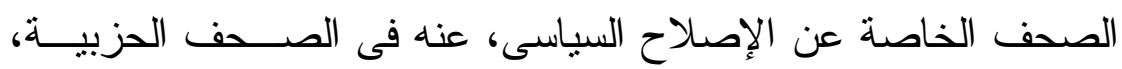
ويذهب المبحوثون إلى أن الصحف الخاصة كانت أكثر موضوعية مـن الصحف الحزبية. كما أثنارت الدراسة إلى أن قر اء الصحف الحزبية حققو ا درجة أعلـى

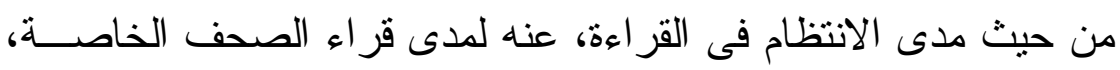

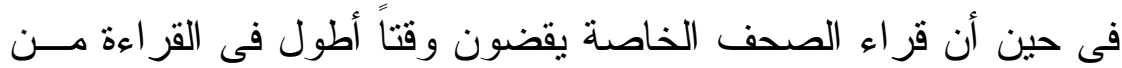
قر اء الصحف الحزبية. V حققت جريدة الوفد أعلى نسبة فى معدل القر اهة بين الصحف موضـــوع الدراسة، تليها جريدة صوت الأمة ثم المصرى اليوم، تليها العربى ثـــ

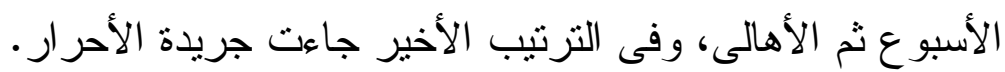

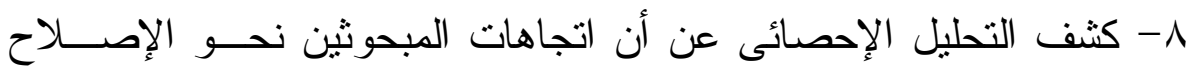
السياسى تتركز حول الاتجاه السلبى. 


\section{هو امش الدراسة}

1) Melvin De fleur and Sandra Rokeach, Theories of mass comm., 4 ed, New York, Longman, 1992, P.261.

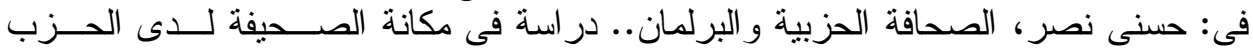

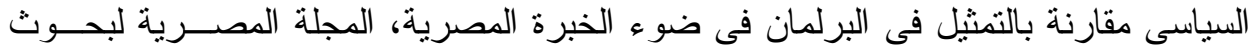

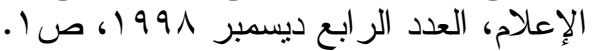

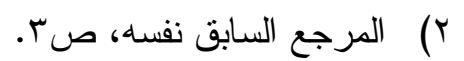

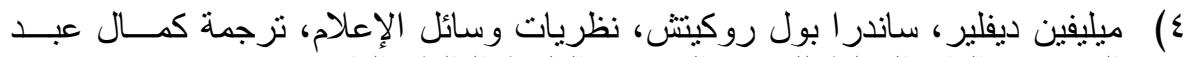

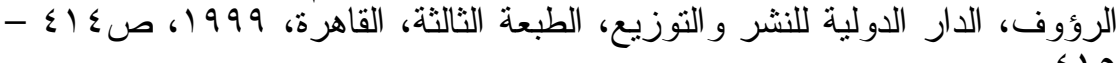

5) Werner J. Setvin and James Wthankrd Jr, communication theories origins, methods and uses in mass media, New York, and London 1992, P262-265.

6) Deflear, Melvin and S. Ball Rokeach, theories of mass communication, New York, Longman, 1992, P.P. 262-264.

$$
\text { ميلفين ديفلير ، ساندر ا بول روكينش، مرجع سابق، ص.ص (V }
$$

8) Elliot, William R. and Rosenberg, William L., Media Exposure and Beliefs about science and technology, communication Research, vol. 14, 2, April 1987.

9) Grant A.E. and Ball Rokeach S.J. Television shopping: media system dependency perspective, communication research, 18 (6) 1991.

10) Azza Abd Elazim, Television Dependency and knowledge of Drug abuse among Egyptian adults, Auc, 1993.

11) Mc Donald, Investing Assumption of Media Dependency Research, communication, vol-10, No 41, 1993.

12) Helpern P. Media dependency and political perceptions in an authoritarian political system, journal of communication 44 (4), 1994.

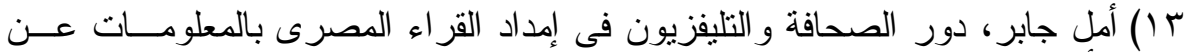

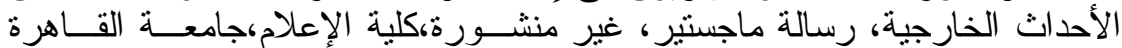

.1997

ع ا) ر اجية أحمد قنديل، صورة مصر لدى الرأى العام الأمريكى، در اســـة اســتطلاعية،

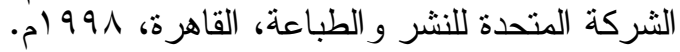




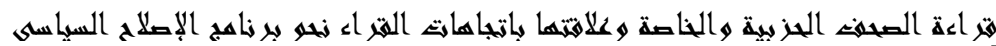

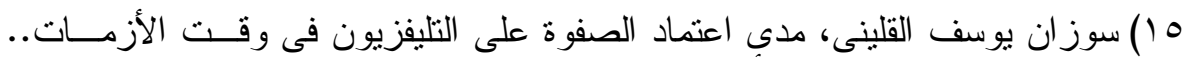

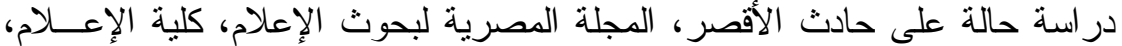

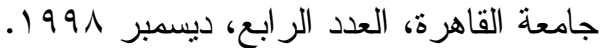

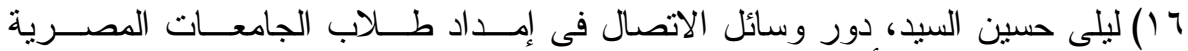

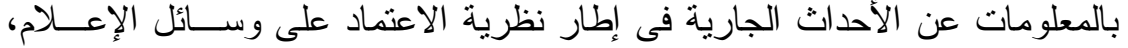

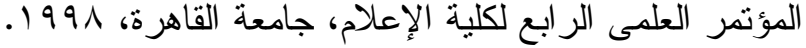

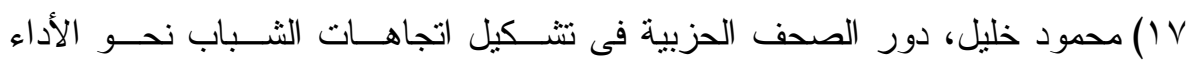

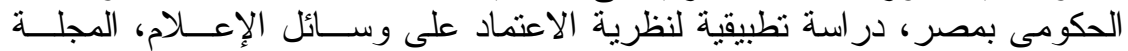

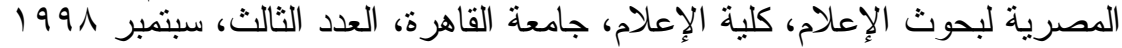

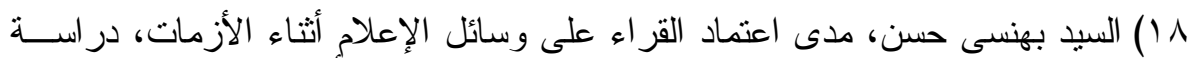

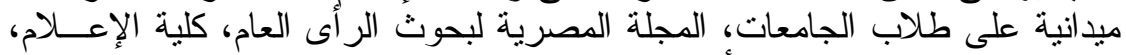
جامعة القاهرة، العدد الر ابع، أكتوبر ... Y.

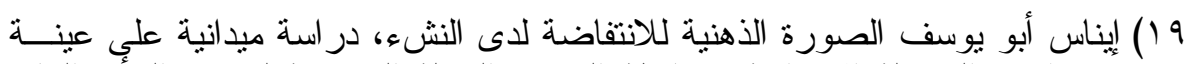

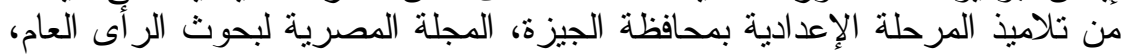

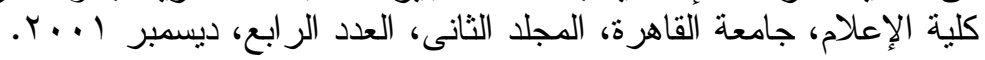

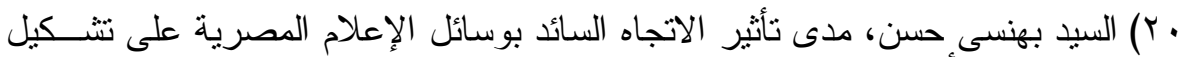

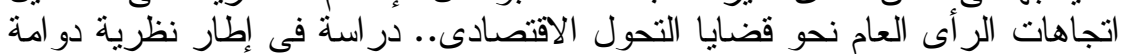

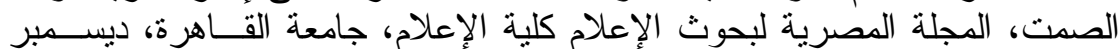
.r. . l

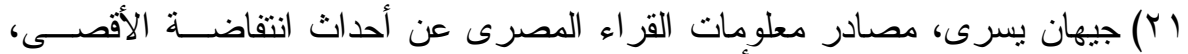

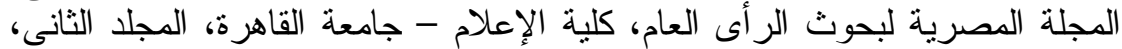

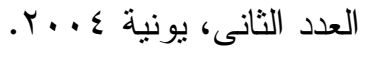

22) Paul Husselbee and Larry Elliot, How national and regional news papers framed hare crimes in jasper, TEXAS and Laramie, Wyoming, journalism and mass communication quarterly, vol No. 4, winter 2002.

23) Patricea May and others, journalism and mass communication, quarterly, vol.80, No, 2, summer 2003.

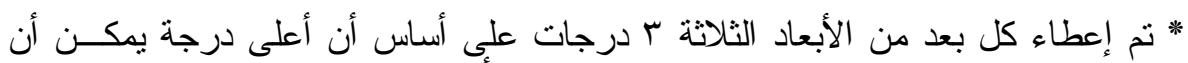

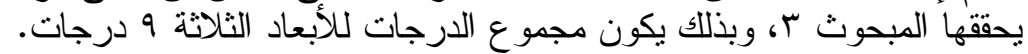

